NBER WORKING PAPER SERIES

MACRO FISCAL POLICY IN ECONOMIC UNIONS:

STATES AS AGENTS

Gerald Carlino

Robert P. Inman

Working Paper 19559

http://www.nber.org/papers/w19559

\author{
NATIONAL BUREAU OF ECONOMIC RESEARCH \\ 1050 Massachusetts Avenue \\ Cambridge, MA 02138 \\ October 2013
}

We thank Pablo Guerron, James Nason, Keith Still, and Tom Stark for helpful comments and Jake Carr and Adam Scavatti for outstanding research assistance. The views expressed here are those of the authors and do not necessarily represent the views of the Federal Reserve Bank of Philadelphia, the Federal Reserve System, or the University of Pennsylvania. The views expressed herein are those of the authors and do not necessarily reflect the views of the National Bureau of Economic Research.

NBER working papers are circulated for discussion and comment purposes. They have not been peerreviewed or been subject to the review by the NBER Board of Directors that accompanies official NBER publications.

(C) 2013 by Gerald Carlino and Robert P. Inman. All rights reserved. Short sections of text, not to exceed two paragraphs, may be quoted without explicit permission provided that full credit, including $\odot$ notice, is given to the source. 
Macro Fiscal Policy in Economic Unions: States as Agents

Gerald Carlino and Robert P. Inman

NBER Working Paper No. 19559

October 2013

JEL No. E62,H39,H77

\begin{abstract}
$\underline{\text { ABSTRACT }}$
The American Recovery and Reinvestment Act (ARRA) was the US government's fiscal response to the Great Recession. An important component of ARRA's \$796 billion proposed budget was $\$ 318$ billion in fiscal assistance to state and local governments. We examine the historical experience of federal government transfers to state and local governments and their impact on aggregate GDP growth, recognizing that lower-tier governments are their own fiscal agents. The SVAR analysis explicitly incorporates federal intergovernmental transfers, disaggregated into project (e.g., infrastructure) aid and welfare aid, as separate fiscal policies in addition to federal government purchases and federal net taxes on household and firms. A narrative analysis provides an alternative identification strategy. To better understand the estimated aggregate effects of aid on the economy, we also estimate a behavioral model of state responses to such assistance. The analysis reaches three conclusions. First, aggregate federal transfers to state and local governments are less stimulative than are transfers to households and firms. It is important to evaluate the two policies separately. Second, within intergovernmental transfers, matching (price) transfers for welfare spending are more effective for stimulating GDP growth than are unconstrained (income) transfers for project spending. Matching aid is fully spent on welfare services or middle-class tax relief; half of project aid is saved and only slowly spent in future years. Third, simulations using the SVAR specification suggest ARRA assistance would have been 30 percent more effective in stimulating GDP growth had the share spent on government purchases and project aid been fully allocated to private sector tax relief and to matching aid to states for lower-income support.
\end{abstract}

Gerald Carlino

Federal Reserve Bank of Philadelphia

Research Department

Ten Independence Mall

Philadelphia, Pa 19106

jerry.carlino@phil.frb.org

Robert P. Inman

Department of Finance

Wharton School

University of Pennsylvania

Philadelphia, PA 19104-6367

and NBER

inman@wharton.upenn.edu 


\title{
Macro Fiscal Policy in Economic Unions: States as Agents
}

\author{
by
}

Gerald Carlino and Robert P. Inman

\section{Introduction}

The Great Recession and efforts by the federal government through the American Recovery and Reinvestment Act (ARRA) to stimulate the economy have returned fiscal policy, and in particular the role of state and local governments in such policies, to the center of macroeconomic policy making. Passed within the first two months of President Obama's administration, ARRA has now spent over $\$ 796$ billion to stimulate the private economy toward full employment: $\$ 381$ billion as federal tax relief and expanded unemployment compensation, \$98 billion as direct federal government spending, and $\$ 318$ billion as intergovernmental transfers to state and local governments for education spending ( $\$ 93$ billion), infrastructure spending ( $\$ 70$ billion), financing of lowerincome housing ( $\$ 6$ billion), lower-income Medicaid funding (\$101 billion), and low-income assistance ( $\$ 48$ billion). ${ }^{1}$ The striking features of this legislation have been its scale, clearly the largest fiscal stimulus since the Great Depression, and its reliance upon intergovernmental transfers to state and local governments for implementing central government macroeconomic fiscal policy.

The Great Recession's impact on the economies of the member states of the European Union has been no less damaging, but lacking Union fiscal policies, the burden for recovery has fallen solely to the European Central Bank and to monetary policy. ECB policies have proven only marginally effective, however. As a result, there is growing interest in developing a complementary set of Union fiscal policies for macro stabilization, implemented through an EU fiscal union. Subsidiarity, the guiding principle for the design of EU policies generally, will place a high premium on using the political and administrative structures of member countries for the management and delivery of any Union-wide fiscal stimulus. As in the United States, then, this will mean intergovernmental transfers from the Union government to member states. How should such transfers be designed to maximize their impact on aggregate, Union-wide economic recovery? Our objective here is to provide an answer to this question, both for the possible redesign of US

\footnotetext{
${ }^{1}$ See Recovery.gov/transparency/fundinggoverview/pages/funding.breakdown.aspx.
} 
stabilization policies and as a guide for the design of future fiscal policies within the EU. ${ }^{2}$

Central to our analysis is the view that US states and EU member countries act as fiscal agents of the central government and that intergovernmental transfers from the center to member states will be the primary policy instrument for control of their fiscal choices. Large infusions of central government aid such as ARRA can increase aggregate state or member country government spending and, to the extent aid leads to local tax relief, increase private consumption and investment as well. The resulting increases in public and private spending may then have positive consequences for aggregate job and income growth.

Four recent studies of the local economic impact of ARRA transfers to US state and local governments suggest this was indeed the case for the first year after the receipt of aid; see Wilson (2012), Feyrer and Sacerdote (2011), Chodorow-Reich et al. (2012), and Conley and Dupor (2013). These studies relate changes in state or county employment for the one year after the passage of ARRA to the level of ARRA transfers received by the coincident state or local government, or their contractors, in the previous fiscal year. Each finds a significant positive impact on local private and public employment, with the strongest effects coming from ARRA support for state Medicaid payments. $^{3}$

These local economy results are valuable but leave three questions unanswered. First, while there are measured gains for the local economy receiving assistance, do those gains come at the expense of, or alternatively might they enhance, the job or income gains of neighboring economies? Recent research, by Beetsma and Giuliodori (2011), Auerbach and Gorodnichenko (2013), and Hebous and Zimmermann (2013) studying aggregate interdependencies among EU economies and by Carlino and Inman (2013b) studying economic interdependencies between US states, finds significant spillovers across economic neighbors. Second, because of limitations of the data, the

2 Our lessons may be more general. In most all fiscal systems, whether explicitly federal or unitary, state, provincial, and local governments are a primary provider of nondefense government services, and central government assistance is often an important source of their revenues; see Inman (2007, Table 1). While the lessons here are based on an analysis of a federal economy, the US, they are relevant for any public economy using central government transfers to influence the choices of a local government sector.

${ }^{3}$ Though not our focus here, the central government can also impact local economies through its own spending and tax subsidies paid directly to households and firms. For recent analyses of the effectiveness of these policies, see Nakamura and Steinsson (2011), Cohen, Coval, and Mallory (2011), Fishback and Kachanovskaya (2010), and SuarezSerrato and Wingender (2011). 
local impact studies can only reveal economic changes for, at most, one year after ARRA spending. Over time, do the positive effects stimulate additional economic activity, do they disappear, or do they perhaps turn negative? Third, the local impact studies estimate the effects of ARRA spending as it is spent. But might the state or local government have used ARRA aid to replace its own planned allocations? Federal aid is fungible within state and local government budgets, and the impact studies will miss the economic consequences of subsequent budgetary adjustments. ARRA sought to prevent such substitutions by requiring a "maintenance of effort" but such provisions are unenforceable for all but entirely new programs; see Craig and Inman (1982) generally and Conley and Dupor (2013) for ARRA. ARRA funds were “fungible”supplements to existing state and local programs.

We address each of these questions and provide the first fully integrated analysis of the macro-economic effects of intergovernmental transfers. ${ }^{4}$ We estimate the general equilibrium consequences of such assistance over time, allowing for behavioral responses by state and local governments. We do so by extending the structural vector autoregression (SVAR) approach of Blanchard and Perotti (2002). In contrast to their original specification that combines transfers to state and local governments with transfers to households and firms, we separate out intergovernmental aid as its own policy. In doing so, we drop the implicit assumption that state and local governments are perfect agents for households and firms. In our specification, state and local governments may have their own agendas. If so, intergovernmental transfers may have consequences for the performance of the macroeconomy distinct from those of direct transfers to, or taxation of, households and firms. In addition, we supplement the SVAR analysis with an alternative identification strategy using a narrative specification for federal aid to state and local governments, following Ramey (2011a). Finally, we estimate a model of fiscal choice for state government budgeting for the 48 mainland states for the period 1979-2010 to clarify exactly how federal aid determines state allocations, relating the results of this microeconomic analysis to the estimated impacts of aid on the macroeconomy. We reach three conclusions.

First, disaggregating federal transfers to governments from federal transfers to households

\footnotetext{
${ }^{4}$ Engemann, Owyang, and Zubairy (2008) have estimated a SVAR model to examine the effects of shocks to state and local government spending on GDP, but they left unspecified the source of those shocks or the possible role federal transfers might have played in affecting state and local spending.
} 
and firms is important. From the SVAR analysis, the estimated GDP multipliers for federal net revenues range from -2 to perhaps as much as -3.6; aggregate transfers to state and local governments have a much more modest impact, ranging from .5 to .8. State and local governments are not perfect agents for households and firms, at least with respect to how the two forms of transfers ultimately impact the private economy. We also find it important to further disaggregate federal transfers to state and local governments into transfers for public employees and public infrastructure ("project aid”) and then into aid to fund state and local payments for assistance to lower-income households ("welfare aid”). Estimated GDP multipliers for welfare aid range from 1.6 to 2.3 and are statistically significant; GDP multipliers for project aid range from 0 to 1.0 and are often statistically insignificant. Our results are generally robust to a variety of alternative specifications, identification strategies, and sample periods. The narrative approach identifies more sharply the impact of project aid on GDP and suggests that the project aid multiplier may be closer 1.0 than 0.0 ; the narrative estimates are statistically significant.

Second, estimation of the microeconomic model of state budget behavior helps clarify why welfare aid and project aid have different impacts on the macroeconomy. Extending the important early work of Gramlich $(1978,1979)$ and the more recent work by Taylor (2011) on federal aid and macro policy, we estimate $\$ .50$ of every dollar of project aid is saved and then allocated at the rate of $\$ .10$ a year to future budgets. Of that $\$ .10$, some $\$ .07$ is spent on goods or services and $\$ .03$ is allocated to pay down the stock of outstanding government debt. In contrast, welfare aid is fully spent, allocated first as increased payments to lower income households and then as tax relief for middle-class households paid as lower state taxes previously earmarked to support welfare payments and services. The final incidence of federal aid may also matter. Project aid supports payments to middle-class households; welfare aid is shared between middle-class tax cuts and lower-income transfers. Given that lower-income households may be credit-constrained and thus more likely to spend any given state government transfer or tax cut, larger multipliers for welfare than for project aid may be expected; see Johnson, Parker, and Souleles (2006).

Third, policy simulations based upon the estimated SVAR analysis suggest the impact of ARRA on GDP growth could have been increased by about 30 percent, or the future tax costs roughly reduced by one-third, had ARRA funding been fully allocated to tax relief for households and firms and to welfare aid to state and local governments. ARRA's allocations for direct federal 
purchases and for project aid for state and local government purchases are estimated to have had very modest effects on GDP growth.

Section II presents the framework for our analysis, outlining the SVAR approach and the narrative approach as alternative identification strategies for estimating the impact of federal aid on the aggregate economy. Section III presents our primary results and then tests for the sensitivity of these results against alternative identification assumptions and sample periods. Section IV provides the microeconomic foundation for our macro analysis by specifying and estimating a model of how state governments might allocate federal assistance to spending, tax relief, and net government savings. Section V applies our estimates to provide counterfactual evaluations of the ARRA stimulus as a source of income growth. Section VI discusses the potential applicability of our approach to other federal and non-federal, but decentralized, public economies.

\section{Estimating the Macroeconomic Effects of Federal Aid}

To obtain estimates of the effects of federal aid on the aggregate private economy, we first extend the structural analysis of variance (SVAR) pioneered by Blanchard and Perotti (2002) to explicitly allow for the effects of federal intergovernmental aid and then, as an alternative identification strategy, develop a narrative record of new and abolished federal aid policies to provide a separate time series for exogenous changes in federal intergovernmental aid. Both approaches begin by separating federal transfers to households and firms from federal transfers to the state and local government (SL) sector. All previous research, beginning with Blanchard and Perotti, has defined federal net revenues as federal revenues less transfers to households and firms less transfers paid to state and local governments. Our analysis explicitly recognizes their possible separate effects on the aggregate economy.

We first define federal net revenues per capita (“taxation,” denoted R) as federal taxes and fees less federal transfers paid directly to households and firms. ${ }^{5}$ We then define federal transfers to state and local governments (“aid,” denoted A) as all federal transfers to the SL sector including

\footnotetext{
${ }^{5}$ Following Blanchard and Perotti (2002), we specify federal net revenues (R) as federal government receipts minus federal government social security benefits to persons minus federal government interest paid. In addition, we treat tobacco settlement payments to states as a de facto federal tax on firms, then transferred as part of federal aid to the state and local sector.
} 
federal aid to support income transfers and public services for lower-income households (most importantly, health care services). Total federal aid is then separated into its two main components: general revenue sharing plus project aid (denoted AP) and public welfare plus Medicaid aid (denoted AW): A = AP + AW. ${ }^{6}$ This distinction will prove important in our empirical results. The third fiscal policy is direct federal purchases of goods and service ("spending," denoted G). ${ }^{7}$ Not explicitly modeled, but implicit in our aggregate analysis, are state and local government purchases and state and local net revenues.

Figure 1 shows the time pattern of total federal aid per capita (A), federal project aid (AP), and federal welfare aid (AW) over the postwar period 1947:1 to 2010:3. The shaded bands indicate periods of economic recessions as dated by the NBER. Real federal aid per capita (2005 dollars) has risen from \$47/person in 1947 to $\$ 1,787 /$ person in 2009:1, the last date before the implementation of President Obama's ARRA fiscal stimulus. ARRA spending over the following year increased aggregate federal aid per capita to $\$ 2,081$ person. During this period, total federal aid as a share of GDP rose from 4/10s of 1 percent in 1947 to 4.3 percent just before the implementation of ARRA. For comparison, Figure 2 shows the time path of federal purchases of

6 General revenue sharing/project aid (AP) includes general revenue sharing, elementary and secondary education aid, model cities and urban renewal aid, transportation aid, all federal aid programs meant to assist SL government finances after recessions (including ARRA's “stability aid”), and tobacco settlement payments; see Carlino and Inman (2013a) for full details. The tobacco settlement payments are viewed as de facto "federal aid” financed by a "tax" on tobacco companies with revenues earmarked to SL spending for smoking prevention and health care expenses. This interpretation of the tobacco settlement as federal aid has some political plausibility as well, since the threat of a direct federal intervention was a strong stimulus for the final, private sector settlement. Settlement payments are unconstrained transfers, fungible across the entire state budget; see Singhal (2008). The two federal aid programs included in AW are Aid to Families with Dependent Children (AFDC) and Medicaid. Federal welfare aid is paid as a grant that matches the states' own spending on welfare services, where the administration of payments is lagged with payments in a given fiscal year based upon expenditures from the prior year and then a final quarter adjustment based on lagged expenditures in the previous three quarters. For this reason we assume AW in any quarter is exogenous to spending in that quarter. When measuring AP and AW we specifically allow for the change in funding structure under the Personal Responsibility and Work Opportunity Reconciliation Act of 1996 (PRWORA). Beginning in 1997, PRWORA transformed funding for public welfare from its historical structure as a matching aid program - Aid to Families with Dependent Children (AFDC) - to an unconstrained, lump-sum transfer known as Temporary Assistance for Needy Families (TANF). When specifying AW and AP we remove AFDC from AW and add TANF to AP; see Table 1 and Carlino and Inman (2013a). Data for AP and AW are from Historical Tables: Budget of the U.S. Government, Fiscal Year, 2011, Office of Management and Budget (Tables 12.2 and 12.3). Tobacco settlement payments are from Funds by State From Settlement Agreement, Center for Social Gerontology, Inc., Ann Arbor, MI. All aid variables are given in annual terms and converted to quarterly frequencies.

${ }^{7}$ Federal purchases of goods and services are specified as federal government purchases of goods and services plus federal defense spending plus federal gross investment. 
goods and services (G) and of federal net revenues (R). Federal purchases rose from \$2,190/person in 1947 (8 percent of GDP) to \$5,195/person in 2009:1 (13 percent of GDP) with an additional $\$ 506 /$ person increase since the implementation of ARRA. Federal net revenues (= revenues payments to households) have risen from \$1638/person in 1947 (13 percent of GDP) to \$1,775/person in 2009:1 (4.3 percent of GDP) with a reduction of \$374/person following ARRA. ${ }^{8}$

A. SVAR Specification and Identification: We begin by estimating a four variable SVAR for the impact of federal net revenues (R), federal government purchases (G), and aggregate federal aid (A) on national GDP (Y). The SVAR analysis begins with the estimation of a reduced form VAR specified as:

$$
\begin{gathered}
\mathbf{Z}_{\mathrm{t}}=\mathrm{C}(\mathrm{L}, \mathrm{q}) \cdot \mathbf{Z}_{\mathrm{t}-1}+\mathbf{u}_{\mathrm{v}} \text {, where } \\
\mathbf{Z}_{\mathrm{t}}{ }^{\prime}=\left[\mathrm{r}_{\mathrm{t}}, \mathrm{g}_{\mathrm{t}}, \mathrm{a}_{\mathrm{t}}, \mathrm{y}_{\mathrm{t}}\right],
\end{gathered}
$$

and where $r_{r}$ is the log of federal net household revenues $(R)$, $g_{t}$ is the log of federal government purchases $(G)$, $a_{t}$ is the log of aggregate federal aid (A), and $y_{t}$ is the log of GDP (Y), each measured at quarterly intervals and measured as real (2005) dollars per capita. Also included in the initial VAR are the trend variables time and time squared, and an indicator variable for "deep recessions" ( $=1$, if the national rate of unemployment exceeds 8 percent). The lag structure $C(L, q)$ is a $4 \times 4$ matrix of three-quarter distributed lag polynomials, and $\mathbf{u}_{\mathbf{t}}$ is a $4 \times 1$ vector of reduced form innovations, specified as $\mathbf{u}_{\mathrm{t}}{ }^{\prime}=\left[\mathrm{u}_{\mathrm{t}}^{\mathrm{r}}, \mathrm{u}_{\mathrm{t}}^{\mathrm{g}}, \mathrm{u}_{\mathrm{t}}^{\mathrm{a}}, \mathrm{u}_{\mathrm{t}}^{\mathrm{y}}\right]$. The three quarter lag allows for seasonal patterns in the responses of fiscal variables to GDP. The AIC test statistic indicates that three lags of the endogenous variables are optimal; three lags are also sufficient to remove serial correlation from the residuals.

To recover the exogenous structural shocks to net federal government revenues, federal government purchases, and federal aid, denoted as $v_{t}^{r}, v_{t}^{g}$, and $v_{t}^{a}$, respectively, we follow the methodology of Blanchard and Perotti. First, we take advantage of quarterly variation in our data and impose the restriction that discretionary changes in fiscal policy take at least one quarter to respond to changes in GDP. Thus the contemporaneous discretionary response of net revenues, purchases, or aid to GDP is zero.

\footnotetext{
${ }^{8}$ The declining share of net revenues in GDP is due to the disproportionate growth in government transfers to households over the past 60 years. Gross federal government revenues equal 16 percent of GDP today and gross transfers equal 11.7 percent of GDP. The difference is 4.3 percent.
} 
Second, we impose constraints on the ordering of discretionary policy changes, requiring discretionary revenues to be set prior to discretionary spending for either purchases or aid, and then within spending, that purchases (largely defense spending) are set prior to federal aid to the SL sector. The priority of discretionary revenue changes is a result of the institutional rules established by the Congressional Budget and Impoundment Control Act of 1974 and subsequent legislation aimed at establishing a revenue-driven budget constraint for federal fiscal policies; see Keith and Schick (2004) and Auerbach (2003). Formally, federal net revenues are seen to Granger-cause federal purchases. ${ }^{9}$ We assume discretionary government purchases predetermine spending for federal aid as, politically, defense spending "trumps” discretionary domestic spending. However, we cannot rule out the possibility that domestic spending may hold priority over defense spending by a Granger-causality test. ${ }^{10}$

Third, we identify the built-in responses of federal tax and transfer policies and federal purchases to contemporaneous changes in GDP following the specifications proposed originally by Blanchard and Perotti (2002). The built-in contemporaneous elasticity of federal net household revenues to changes in GDP is set equal to 2.08, while the built-in contemporaneous elasticity of government purchases with respect to GDP is set at 0.0 , reflecting the largely contractual nature of these outlays. These estimates come from outside the model and represent the automatic stabilizers for federal net household revenues and government purchases, respectively. We test the sensitivity of our results to alternative estimates of the contemporaneous revenue elasticity, ranging from 1.6 based on direct estimates for the US economy by Follette and Lutz (2010) to 3.0 based upon estimates by Mountford and Uhlig (2009) and Mertens and Ravn (2013) using the SVAR specification. An estimate of the contemporaneous built-in effects of GDP on federal aid to the SL sector is obtained from a panel regression for the period 1970-2010 relating the log of total federalto-state aid to the log of gross state product (GSP) conditional on year and state fixed effects; our

${ }^{9}$ For the full sample period (1947:1 to 2010:3) we reject the null hypothesis that revenues do not Granger-cause spending $\left(\chi^{2}=14.01\right)$, but we cannot reject the null that spending does not Granger-cause revenues $\left(\chi^{2}=3.84\right)$.

10 For the full sample period (1947:1 to 2010:3) we cannot reject either the null hypothesis that federal aid Granger-causes federal purchases $\left(\chi^{2}=14.26\right)$ or the null hypothesis that federal purchases Granger-cause federal aid. We have tested for the sensitivity of our core results to the alternative ordering that places domestic spending politically "prior" to defense spending, and the results remain essentially the same. 
preferred estimate is $-.35 .^{11}$

Formally, the vector of reduced form residuals is specified as a linear combination of structural shocks:

$$
\begin{aligned}
& \mathrm{u}_{\mathrm{t}}^{\mathrm{r}}=\alpha_{\mathrm{r}, \mathrm{y}} \cdot \mathrm{u}_{\mathrm{t}}^{\mathrm{y}}+\beta_{\mathrm{r}, \mathrm{g}} \bullet \mathrm{v}_{\mathrm{t}}^{\mathrm{g}}+\beta_{\mathrm{r}, \mathrm{a}} \bullet \mathrm{v}_{\mathrm{t}}^{\mathrm{a}}+\mathrm{v}_{\mathrm{t}}^{\mathrm{r}}, \\
& \mathrm{u}_{\mathrm{t}}^{\mathrm{g}}=\alpha_{\mathrm{g}, \mathrm{y}} \bullet \mathrm{u}_{\mathrm{t}}^{\mathrm{y}}+\beta_{\mathrm{g}, \mathrm{r}} \bullet \mathrm{v}_{\mathrm{t}}^{\mathrm{r}}+\beta_{\mathrm{g}, \mathrm{a}} \bullet \mathrm{v}_{\mathrm{t}}^{\mathrm{a}}+\mathrm{v}_{\mathrm{t}}^{\mathrm{g}}, \\
& \mathrm{u}_{\mathrm{t}}^{\mathrm{a}}=\alpha_{\mathrm{a}, \mathrm{y}} \cdot \mathrm{u}_{\mathrm{t}}^{\mathrm{y}}+\beta_{\mathrm{a}, \mathrm{g}} \bullet \mathrm{v}_{\mathrm{t}}^{\mathrm{g}}+\beta_{\mathrm{a}, \mathrm{r}} \bullet \mathrm{v}_{\mathrm{t}}^{\mathrm{r}}+\mathrm{v}_{\mathrm{t}}^{\mathrm{a}}, \\
& \mathrm{u}_{\mathrm{t}}^{\mathrm{y}}=\alpha_{\mathrm{y}, \mathrm{r}} \cdot \mathrm{u}_{\mathrm{t}}^{\mathrm{r}}+\alpha_{\mathrm{y}, \mathrm{g}} \cdot \mathrm{u}_{\mathrm{t}}^{\mathrm{g}}+\alpha_{\mathrm{y}, \mathrm{a}} \cdot \mathrm{u}_{\mathrm{t}}^{\mathrm{a}}+\mathrm{v}_{\mathrm{t}}^{\mathrm{y}} \cdot
\end{aligned}
$$

Netting out all contemporaneous responses among the reduced form residuals implies:

$$
\begin{aligned}
& \mathrm{u}^{\mathrm{C}, \mathrm{r}}{ }_{\mathrm{t}} \equiv\left(\mathrm{u}_{\mathrm{t}}^{\mathrm{r}}-\alpha_{\mathrm{r}, \mathrm{y}} \cdot \mathrm{u}_{\mathrm{t}}^{\mathrm{y}}\right)=\beta_{\mathrm{r}, \mathrm{g}} \bullet \mathrm{v}_{\mathrm{t}}^{\mathrm{g}}+\beta_{\mathrm{r}, \mathrm{a}} \bullet \mathrm{v}_{\mathrm{t}}^{\mathrm{a}}+\mathrm{v}_{\mathrm{t}}^{\mathrm{r}}, \\
& \mathrm{u}^{\mathrm{C}, \mathrm{g}}{ }_{\mathrm{t}} \equiv\left(\mathrm{u}_{\mathrm{t}}^{\mathrm{g}}-\alpha_{\mathrm{g}, \mathrm{y}} \cdot \mathrm{u}^{\mathrm{y}}\right)=\beta_{\mathrm{g}, \mathrm{r}} \cdot \mathrm{v}_{\mathrm{t}}^{\mathrm{r}}+\beta_{\mathrm{g}, \mathrm{a}} \bullet \mathrm{v}_{\mathrm{t}}^{\mathrm{a}}+\mathrm{v}_{\mathrm{t}}^{\mathrm{g}}, \\
& \mathrm{u}^{\mathrm{C}, \mathrm{a}}{ }_{\mathrm{t}} \equiv\left(\mathrm{u}_{\mathrm{t}}^{\mathrm{a}}-\alpha_{\mathrm{a}, \mathrm{y}} \bullet \mathrm{u}_{\mathrm{t}}^{\mathrm{y}}\right)=\beta_{\mathrm{a}, \mathrm{g}} \bullet^{\mathrm{v}} \mathrm{v}_{\mathrm{t}}^{\mathrm{g}}+\beta_{\mathrm{a}, \mathrm{r}} \bullet \mathrm{v}_{\mathrm{t}}^{\mathrm{r}}+\mathrm{v}_{\mathrm{t}}^{\mathrm{a}}, \\
& \mathrm{u}^{\mathrm{C}, \mathrm{y}}{ }_{\mathrm{t}} \equiv\left(\mathrm{u}_{\mathrm{t}}^{\mathrm{y}}-\alpha_{\mathrm{y}, \mathrm{r}} \cdot \mathrm{u}_{\mathrm{t}}^{\mathrm{r}}-\alpha_{\mathrm{y}, \mathrm{g}} \cdot \mathrm{u}_{\mathrm{t}}^{\mathrm{g}}-\alpha_{\mathrm{y}, \mathrm{a}} \cdot \mathrm{u}_{\mathrm{t}}^{\mathrm{a}}\right)=\mathrm{v}_{\mathrm{t}}^{\mathrm{y}},
\end{aligned}
$$

where each coefficient $\alpha_{p, y}$ specifies the built-in (programmatic) elasticity of fiscal policy (p = r, g, a) to GDP and each coefficient $\alpha_{y, p}$ the response of GDP to contemporaneous (including exogenous) changes in each fiscal policy $(\mathrm{p}=\mathrm{r}, \mathrm{g}, \mathrm{a})$.

Our initial estimates set $\alpha_{\mathrm{r}, \mathrm{y}}=2.08, \alpha_{\mathrm{g}, \mathrm{y}}=0$, and $\alpha_{\mathrm{a}, \mathrm{y}}=-$.35. From the identification strategy for the timing of fiscal policy decision-making we set $\beta_{\mathrm{r}, \mathrm{g}}=\beta_{\mathrm{r}, \mathrm{a}}=0$ from the priority of federal revenues over spending and $\beta_{\mathrm{g}, \mathrm{a}}=0$ from the priority of government purchases over SL aid. With these restrictions, the resulting specification is identified and allows us to estimate the remaining six free parameters $\left(\beta_{\mathrm{g}, \mathrm{r}}, \beta_{\mathrm{a}, \mathrm{g}}, \beta_{\mathrm{a}, \mathrm{r}}, \alpha_{\mathrm{y}, \mathrm{r}}, \alpha_{\mathrm{y}, \mathrm{g}}, \alpha_{\mathrm{y}, \mathrm{a}}\right)$ and to compute a distribution for the exogenous structural errors, $\mathbf{v}_{\mathbf{t}}{ }^{\prime}=\left[\mathrm{v}_{\mathrm{t}}^{\mathrm{r}}, \mathrm{v}_{\mathrm{t}}^{\mathrm{g}}, \mathrm{v}_{\mathrm{t}}^{\mathrm{a}}, \mathrm{v}_{\mathrm{t}}^{\mathrm{y}}\right]$. Returning to the estimated reduced form VAR specification, we can then estimate impulse response functions for GDP following exogenous shocks in fiscal policy.

A similar specification and identification strategy applies when the analysis is extended to a five variable SVAR. Now the vector of policies and GDP is specified as $\mathbf{Z}^{\prime}=\left[\mathrm{r}_{\mathrm{t}}, \mathrm{g}_{\mathrm{t}}, \mathrm{aw}_{\mathrm{t}}, \mathrm{ap}_{\mathrm{t}}, \mathrm{y}_{\mathrm{t}}\right]$, where $\mathrm{aw}_{\mathrm{t}}$ is the log of federal matching aid for state-funded transfers to lower-income households (AW) and $\mathrm{ap}_{\mathrm{t}}$ is the log of federal project aid for general state and local government spending or tax

11 The estimated coefficient of total aid with respect to current state GSP is significant at the .95 level of confidence. The key identifying assumption is that any effects of federal aid on state incomes - say through the construction of public infrastructure - take at least a year to impact state incomes. The negative coefficient reflects the built-in redistributive component of most federal aid programs; see Melitz and Zumer (2002). 
relief (AP). The corresponding vector of exogenous residuals to be estimated is now $\mathbf{v}_{\mathbf{t}}{ }^{\prime}=\left[\mathrm{v}_{\mathrm{t}}^{\mathrm{r}}, \mathrm{v}_{\mathrm{t}}^{\mathrm{g}}\right.$, $\left.\mathrm{v}^{\mathrm{aw}}{ }_{\mathrm{t}}, \mathrm{v}^{\mathrm{ap}}{ }_{\mathrm{t}}, \mathrm{v}_{\mathrm{t}}^{\mathrm{y}}\right]$. The five variable SVAR is specified as:

$$
\begin{aligned}
& \mathrm{u}^{\mathrm{C}, \mathrm{r}}{ }_{\mathrm{t}} \equiv\left(\mathrm{u}_{\mathrm{t}}^{\mathrm{r}}-\alpha_{\mathrm{r}, \mathrm{y}} \bullet \mathrm{u}_{\mathrm{t}}^{\mathrm{y}}\right)=\beta_{\mathrm{r}, \mathrm{g}} \bullet \mathrm{v}_{\mathrm{t}}^{\mathrm{g}}+\beta_{\mathrm{r}, \mathrm{aw}} \bullet \mathrm{v}^{\mathrm{aw}}{ }_{\mathrm{t}}+\beta_{\mathrm{r}, \mathrm{ap}} \bullet \mathrm{v}^{\mathrm{ap}}{ }_{\mathrm{t}}+\mathrm{v}_{\mathrm{t}}^{\mathrm{r}} \text {, } \\
& \mathrm{u}^{\mathrm{C}, \mathrm{g}}{ }_{\mathrm{t}} \equiv\left(\mathrm{u}_{\mathrm{t}}^{\mathrm{g}}-\alpha_{\mathrm{g}, \mathrm{y}} \cdot \mathrm{u}_{\mathrm{t}}^{\mathrm{y}}\right)=\beta_{\mathrm{g}, \mathrm{r}} \bullet^{\mathrm{r}}{ }_{\mathrm{t}}+\beta_{\mathrm{g}, \mathrm{aw}} \cdot \mathrm{v}^{\mathrm{aw}}{ }_{\mathrm{t}}+\beta_{\text {g,ap }} \bullet \mathrm{v}^{\mathrm{ap}}{ }_{\mathrm{t}}+\mathrm{v}_{\mathrm{t}}^{\mathrm{g}} \text {, } \\
& \mathrm{u}^{\mathrm{C}, \mathrm{aw}}{ }_{\mathrm{t}} \equiv\left(\mathrm{u}^{\mathrm{aw}}{ }_{\mathrm{t}}-\alpha_{\mathrm{aw}, \mathrm{y}} \cdot \mathrm{u}_{\mathrm{t}}^{\mathrm{y}}\right)=\beta_{\mathrm{aw}, \mathrm{r}} \cdot \mathrm{v}_{\mathrm{t}}^{\mathrm{r}}+\beta_{\mathrm{aw}, \mathrm{g}} \cdot \mathrm{v}_{\mathrm{t}}^{\mathrm{g}}+\beta_{\mathrm{aw}, \mathrm{ap}} \cdot \mathrm{v}^{\mathrm{ap}}{ }_{\mathrm{t}}+\mathrm{v}^{\mathrm{aw}}{ }_{\mathrm{t}} \text {, } \\
& \mathrm{u}^{\mathrm{C}, \mathrm{ap}}{ }_{\mathrm{t}} \equiv\left(\mathrm{u}^{\mathrm{ap}}{ }_{\mathrm{t}}-\alpha_{\mathrm{ap}, \mathrm{y}} \cdot \mathrm{u}_{\mathrm{t}}^{\mathrm{y}}\right)=\beta_{\mathrm{ap}, \mathrm{r}} \cdot \mathrm{v}_{\mathrm{t}}^{\mathrm{r}}+\beta_{\mathrm{ap}, \mathrm{g}} \cdot \mathrm{v}_{\mathrm{t}}^{\mathrm{g}}+\beta_{\mathrm{ap}, \mathrm{aw}} \cdot \mathrm{v}^{\mathrm{aw}}{ }_{\mathrm{t}}+\mathrm{v}^{\mathrm{ap}}{ }_{\mathrm{t}} \text {, } \\
& \mathrm{u}^{\mathrm{C}, \mathrm{y}}{ }_{\mathrm{t}} \equiv\left(\mathrm{u}_{\mathrm{t}}^{\mathrm{y}}-\alpha_{\mathrm{y}, \mathrm{r}} \cdot \mathrm{u}_{\mathrm{t}}^{\mathrm{r}}-\alpha_{\mathrm{y}, \mathrm{g}} \cdot \mathrm{u}_{\mathrm{t}}^{\mathrm{g}}-\alpha_{\mathrm{y}, \mathrm{aw}} \cdot \mathrm{u}^{\mathrm{aw}}{ }_{\mathrm{t}}-\alpha_{\mathrm{y}, \mathrm{ap}} \cdot \mathrm{u}^{\mathrm{ap}}{ }_{\mathrm{t}}\right)=\mathrm{v}_{\mathrm{t}}^{\mathrm{y}} \text {, }
\end{aligned}
$$

where we again specify $\alpha_{\mathrm{r}, \mathrm{y}}=2.08$ and $\alpha_{\mathrm{g}, \mathrm{y}}=0 ; \beta_{\mathrm{r}, \mathrm{g}}=\beta_{\mathrm{r}, \mathrm{aw}}=\beta_{\mathrm{r}, \mathrm{ap}}=0$ by the budgetary priority of revenue over spending; and $\beta_{\mathrm{g}, \mathrm{aw}}=\beta_{\mathrm{g}, \mathrm{ap}}=0$ from the budgetary priority of government purchases (largely defense) over grants to the SL sector. Initially we specify formula welfare aid as prior in budgeting to discretionary federal program aid and set $\beta_{\text {aw,ap }}=0$. For the five variable SVAR, we use estimates of the contemporaneous built-in effects of GDP on the two components of federal aid, again obtained from state panel regressions now relating the log of welfare and program aid to the log of gross state product (GSP), conditional on year and state fixed effects. Here the preferred estimates are $\alpha_{\mathrm{ap}, \mathrm{y}}=-.40$ and $\alpha_{\mathrm{aw}, \mathrm{y}}=-.19{ }^{12}$ With these restrictions, the resulting specification in (3) is identified and allows us to estimate the remaining 10 free parameters $\left(\beta_{\mathrm{g}, \mathrm{r}}, \beta_{\mathrm{aw}, \mathrm{r}}, \beta_{\mathrm{aw}, \mathrm{g}}, \beta_{\mathrm{ap}, \mathrm{r}}, \beta_{\mathrm{ap}, \mathrm{g}}, \beta_{\mathrm{ap}, \mathrm{aw}}, \alpha_{\mathrm{y}, \mathrm{r}}, \alpha_{\mathrm{y}, \mathrm{g}}\right.$, $\left.\alpha_{\mathrm{y}, \mathrm{aw}}, \alpha_{\mathrm{y}, \mathrm{ap}}\right)$ and the resulting vector of exogenous residuals $\mathbf{v}_{\mathrm{t}}{ }^{\prime}=\left[\mathrm{v}_{\mathrm{t}}^{\mathrm{r}}, \mathrm{v}_{\mathrm{t}}^{\mathrm{g}}, \mathrm{v}^{\mathrm{aw}}{ }_{\mathrm{t}}, \mathrm{v}_{\mathrm{v}}^{\mathrm{ap}}, \mathrm{v}_{\mathrm{t}}^{\mathrm{y}}\right]$. This specification allows us to estimate separate GDP impulse response functions for welfare aid (AW) and program aid (AP).

B. Narrative Specification and Identification: The SVAR approach to identification of exogenous policy shocks is model dependent with correct identification conditional upon the a priori specification for the timing of policy choices and the contemporaneous influence of GDP on policies. While testing for the robustness of policy responses to alternative SVAR specifications is important (and we do so below), the use of policy narratives first proposed by Ramey and Shapiro (1998) for federal spending and recently applied to tax policy by Romer and Romer (2010) provides an alternative identification strategy. The important issue is, when does the private sector, and for us

12 Each estimated elasticity is significant at the .95 level of confidence. Again, the negative coefficient measures the redistributive nature of most federal aid to SL governments. The lower elasticity for welfare aid likely reflects the low elasticity of permanent poverty to annual, within-state changes in GSP and then the slow rate of take-up of residents to income support and Medicaid programs. 
the SL sector as well, anticipate the implementation of the new federal policy and begin to adjust its economic choices? A failure to appropriately identify the announced date of the policy innovation will lead to biased estimates as to the policy’s impacts on the private economy; see Leeper, Walker, and Yang (2010) and Ramey (2011a). For example, policies may look ineffective if agents anticipate an innovation occurring before the econometrician's assumed date for the innovation. The narrative approach to identification is independent of the econometrician's model and relies upon political histories of the fiscal policies to identify both the likely exogeneity of policies from changes in GDP and the dates when the policies are implemented. ${ }^{13}$

We have developed the narrative history for federal aid to state and local governments from 1947 to the 2009 adoption of the American Recovery and Reinvestment Act (ARRA); see Carlino and Inman (2013a). Table 1 provides a summary of the narrative dates for all important new federal aid programs since $1947 .{ }^{14}$ Our narrative approach identifies 21 separate narrative events, 18 where federal aid is increased and three where aid is reduced. Two decisions are required to specify the value of the narrative aid event: first, the level of new aid and, second, the timing of the innovation. We specify the level of aid available from the new program as the amount appropriated for

\footnotetext{
${ }^{13}$ It is also important that the narrative estimates of aid innovations be independent of - that is not responsive to - contemporaneous increases or decreases in GDP. This will be true for policy innovations in US federal aid with the possible exceptions of the Public Works Employment Act of 1976, the Economic Stimulus Appropriation Act of 1977, the Intergovernmental Recession Act of 1977, and the reauthorization of CETA (each a policy response to the recession of 1973-75), the Emergency Jobs Act of 1983 (a response to the 1981-82 recession), the Job Growth and Tax Reconciliation Act of 2003 (a response to the 2001 recession), and ARRA in 2009 (a response to the Great Recession of 2007-09). For all these policies, aid was approved after the recessions had ended. However, it is possible that state and local government officials would have anticipated these policy responses by Congress and begun a budget adjustment before aid was to be received. We therefore allow for anticipated federal aid under each policy as follows. First, the four policies approved in response to the 1973-75 recession are treated as true innovations as Congress had not offered post-recession fiscal assistance at any time prior to these four policies. After 1978, however, post-recession aid may have been expected. Second, we therefore assume that states would have anticipated assistance sufficient to cover their deficits accumulated during the recessions; see National Association of State Budget Officers (NASBO), The Fiscal Survey of the States, recession years. Only new program aid funding above or below the accumulated recession deficits is treated as a policy innovation. Third, there were no new programs following the recession of 1990-91, but there were state deficits. We treat the failure to pass a policy following this recession as a negative policy innovation. See Carlino and Inman (2013a: Addendum: Is Federal Aid Expected in Downturns?).

${ }^{14}$ The narrative analysis does not include changes in the federal tax code that impact state and local government revenues, most notably through changes in the federal definition of taxable income used by many states in setting their own tax base. The reason for excluding these policy changes is that the resulting changes in state revenues arise from transfers between residents within a state. Our focus here is on changes in revenues paid to states from those outside the state and viewed by residents - Ricardian arguments aside - as exogenous increases in state and local governments' budget constraints. For an analysis of the impact of within state revenue "shocks," see Ladd (1993).
} 
the first full fiscal year of the program's implementation; beyond the initial year, aid is assumed to be anticipated. Because the municipal bond market will only lend against pledged federal assistance within the fiscal year (via Revenue Anticipation Notes, or RANs), ${ }^{15}$ we do not discount future aid except for two innovations. The first is the legislated phased reduction in federal funding of general revenue sharing from 1981 to 1983 for state governments and from 1984 to 1987 for local governments. The second is the tobacco settlement revenue specified in the Master Settlement Agreement with US tobacco companies beginning in 1998:4 and to be paid through 2025. Though paid directly by tobacco firms to states, we treat these revenues as de facto exogenous assistance by the federal government. ${ }^{16}$ Further, these revenue promises are binding contracts between the state and the firms, and for this reason the bond markets have been willing to lend to the states against these promises. Thus the discounted present value of these promises is used as our measure for level of this assistance; see Table 1.

In specifying the timing of an aid innovation, there are three dates on which state and local officials might begin budgeting in anticipation of new federal assistance: (i) the date of introduction of the legislation; (ii) the date of passage by Congress if the legislation had been introduced by the President or the date of signing by the President if there had been a risk of a presidential veto; or (iii) the date of first federal funding. Carlino and Inman (2013a) provide all three dates. Following Mertens and Ravn (2012), we use only the first date that money was actually sent to the SL sector, with one institutional adjustment. We allow for the fact that significant changes in state or local budgets, whether a spending increase or a tax reduction, are typically not allowed by state law once the budget has been adopted at the beginning of a fiscal year. ${ }^{17}$ This means that an aid innovation that occurs in the middle of a state's fiscal year, for example in calendar Q1, cannot be fully incorporated

\footnotetext{
${ }^{15}$ State and local governments' own savings are insufficient for these governments to do their own "borrowing” in anticipation of future aid. Holtz-Eakin, Rosen, and Tilly (1994) provide evidence that the aggregate state and local government sector is credit constrained on their current accounts.

${ }^{16}$ See Singhal (2008). Apart from the budgetary equivalence of settlement funding and lump-sum federal aid, there is a good political reason to treat tobacco settlement funds as de facto federal aid. It was only after Congress threatened to impose its own tax and transfer policy to compensate for state Medicaid costs of tobacco-related illnesses that the tobacco companies agreed to a final settlement.

${ }^{17}$ The one exception is in states with balanced budget rules with a "no carryover" provision. When they are running deficits these states are required to raise revenues or curtail spending to ensure an end-of-fiscal-year balanced budget. Positive narrative events will not be affected by such rules.
} 
into state fiscal decisions until the beginning of the next fiscal year, typically beginning in Q3 and continuing until Q2 of the subsequent calendar year. In these cases we attribute the innovation both to the year when aid money is appropriated (since modest spending might be allowed) and to the next fiscal year when the new funding can be fully incorporated into the state and local budgets. All shocks are annualized. An F-test that real (2005 dollars) per capita narrative aid as defined in Table 1 is a strong instrument for predicting aggregate federal aid per capita has a test statistic of $10.64{ }^{18}$

Estimation of federal aid's impact on the private economy using a narrative identification follows the VAR approach of Ramey (2011a), ordering the aggregate narrative aid variable first, followed by federal net revenues excluding federal aid, federal purchases, and finally GDP. ${ }^{19}$ All variables are now specified in levels to allow for negative innovations. A quadratic time trend and three lags are also included in the specification. Separate narrative estimates are reported for aggregate aid (denoted $\Delta \mathrm{A}$ ) and project aid $(\Delta \mathrm{AP})$. There are only three narrative events that apply to welfare aid, and for this reason we have not separately estimated the impact of welfare aid using narrative identification.

C. Comparing Identification Strategies: In Figure 3 we compare the quarterly time paths for the dollar-equivalent innovations in project aid (Figure 3a) and welfare aid (Figure 3b) as estimated from the SVAR (dotted lines) and the narrative (solid line) approaches. ${ }^{20}$ As summarized in Table 1, the narrative approach captures innovations to aid from the introduction of new policies. The SVAR approach captures not only innovations from new policies but also innovations in how governments administer existing policies. Even though Congress has authorized federal aid spending, the exact timing of expenditures, particularly during any fiscal year, is the responsibility of the President through the decision to appropriate spending. In the case of welfare aid, which is

18 Also included in the federal aid regressions with narrative aid are three lag values of net revenues, government purchases, and federal aid. The $F$ test is for contribution of narrative aid as an explanatory variable for contemporaneous federal aid. A value for the $F$ test statistic above 10 is the generally accepted hurdle for a strong instrument. The sample period for the reported $F$ test is 1960:1 to 2010:3, the primary period for our analysis.

${ }^{19}$ See also Favero and Giavazzi (2012).

${ }^{20}$ The estimates of $\mathrm{v}^{\mathrm{ap}}{ }_{\mathrm{t}}$ and $\mathrm{v}^{\mathrm{aw}}{ }_{\mathrm{t}}$ used to compute the dollar equivalent change for an unexpected shock to project aid and welfare aid are uncovered from the estimated VAR for the specification reported in Table 3, columns (1)-(4). As specified in the SVAR, $\mathrm{v}^{\mathrm{ap}}{ }_{\mathrm{t}}$ and $\mathrm{v}^{\text {aw }}{ }_{\mathrm{t}}$ are measured as innovations to the log of project aid and welfare aid respectively. These percentage innovations were multiplied by the levels of project and welfare aid to obtain dollar equivalent innovations for comparison to the narrative aid innovations, also measured in dollars. 
allocated to match SL spending, appropriations will depend on administrative decisions by governors as well.

The two identification strategies provide alternative estimates for how exogenous aid might causally affect GDP. As first argued by Sims (1998) for monetary policy and recently by Favero and Giavazzi (2012) for fiscal policy, both approaches provide valid estimates as long as the innovations are orthogonal to all other shocks in the VAR that might influence GDP growth. The simple correlation between SVAR and narrative innovations for project aid is .19 and that between SVAR and narrative innovations for welfare aid is .13 . Both correlations are statistically significant at the .95 level of confidence. Having multiple instruments to identify exogenous changes in government policies is analogous to having multiple instruments for identifying shifts in a supply curve - e.g., weather and insects - when estimating a demand curve. In our case, the narrative approach achieves identification from the unexpected introduction of new aid policies, while the SVAR approach achieves identification from both the unanticipated introduction of new policies and from unanticipated changes in aid because of the administration of existing policies.

Figure 3 illustrates that both approaches capture the new policy innovations as detailed in Table 1, while the SVAR innovations also record innovations to federal aid not recorded in the narrative record. The exact reasons for these additional, "administrative" SVAR innovations cannot be identified precisely, but it is perhaps worth noting that the large positive SVAR innovations not accounted for by matching narrative innovations occur only for welfare aid and in years just after recessions, while the large negative SVAR innovations are limited to project aid and occur only within Republican administrations. The one exception to this pattern occurs during the Clinton presidency, when there is the negative SVAR shock to welfare aid in 1996:2 and the positive SVAR shock to project aid soon thereafter in 1997:3. This timing is consistent with the reform of welfare payments to states as part of the Personal Responsibility and Work Opportunity Reconciliation Act of 1996 (PRWORA). The act ended matching aid to states under Aid for Families with Dependent Children (AFDC) and then compensated states with lump-sum assistance under a new program called Temporary Assistance for Needy Families (TANF). AFDC aid was cut (the negative innovation in welfare aid) and TANF aid began (the positive innovation to project aid). In our specification of narrative aid, we have combined these two reforms into a single "new policy" event, where the loss in AFDC aid was slightly larger than the gain in new TANF aid; see Table 1 and Figure 3b over the 
period 1997:3 to 1998:2.

\section{Results}

A. SVAR Results: Tables 2 and 3 present the SVAR estimates of the impact of federal fiscal policy on per capita GDP, first for the four variable SVAR specification (Table 2) and then for the disaggregated federal aid, five variable specification (Table 3). The tables report the estimated fiscal multipliers (impulse responses) by quarters for GDP for a one-time, one dollar change in each of the federal fiscal policies; one standard deviation (68 percent) confidence intervals are reported within parentheses, and an asterisk indicates when the estimated effect is significantly different from zero at a 95 percent level of confidence. To avoid the large breaks in fiscal policy after WWII and from the Korean War, we follow Blanchard and Perotti (2002) and focus our analysis on the period 1960:1 to 2010:3.

For purposes of comparison, columns (1)- (4) in Table 2 reproduce the three variable SVAR of Blanchard-Perotti, first for the full sample period 1947:1 to 2010:3 and then for the post 1960 sample. This initial three variable SVAR adopts the Blanchard-Perotti specification for federal net revenues defined as federal taxes less transfers to households and firms (our R) less federal aid to the SL sector (our A): R - A. The estimates of the impact of federal purchases (G) on GDP in Table 2, columns (2) and (4) are comparable in magnitude ( $\cong 1$ ) and timing (no effects beyond Q8) to the estimates reported by Blanchard and Perotti (2002, Table IV). Our estimates in Table 2, columns (1) and (3) for the impact of net revenues as specified by Blanchard-Perotti (R - A) on GDP are somewhat larger than the estimates of Blanchard and Perotti (2002, Table III) but with comparable time patterns; our peak tax multiplier is -2.1 compared to their peak of -1.3 . Both studies show significant tax multipliers into Q8 after the innovation.

What is central to our analysis is the possible difference between the estimated multipliers for shocks to net revenues for household and firms only (R) and the separate multipliers for shocks to federal SL aid (A); see Table 2, columns (5)-(7). First, estimated multipliers for government purchases $(G)$ are now smaller, peaking at .56, and are statistically significant only in this initial period after the spending innovation, a pattern that holds for the remainder of our analysis and parallels the results in Barro and Redlick (2011) and summarized in Ramey (2011b). Most importantly here, the estimates for this four variable SVAR show federal aid paid to the SL sector 
(A) is far less stimulative of GDP than are taxes paid and transfers received directly by the household sector (R). The peak multiplier for A is .8 and its impact on GDP is exhausted after two years. The peak multiplier for $\mathrm{R}$ is now -3.75 and its impact on GDP lasts into Q12. These results for a household-and-firm-only definition of net revenues are comparable to those reported in Romer and Romer's (2010) narrative study and Mertens and Ravn's (2013) SVAR study for the impacts of tax policy. Both of those studies focus only on taxes and transfers to the private sector, as does our definition of $\mathrm{R}$. The results here suggest it is important to recognize the separate effects on GDP of innovations in transfers to governments and transfers to households. To ignore this distinction will be to overestimate the impacts on GDP of aid to SL governments and to underestimate the impact of taxes and transfers to households and firms.

Table 3, columns (1)-(4) extend our analysis by disaggregating total SL aid into its two primary components, welfare aid (AW) and project aid (AP), and then estimating a five variable SVAR. The estimated effects for federal net revenues and federal spending innovations are comparable to those reported in Table 2. We now observe how innovations in the two forms of federal aid, AP and AW, impact GDP. The effects are significantly different. The multipliers associated with an innovation in project aid (AP) are initially small, negative, and statistically significant, then positive thereafter though never statistically significant; see Table 3, column (3). The negative effect of AP following the innovation mirrors results in Gramlich (1978), who found state and local governments temporarily postponed planned government spending, particularly capital projects, so as to utilize forthcoming federal project aid. In contrast, the multipliers associated with an innovation in welfare aid (AW) are as large as 2.3 (in Q2) and statistically significant into the third year after the innovation; see Table 3, column (4). If the policy strategy is to use state and local governments, and thus SL aid, to stimulate the private economy during a recession, then welfare aid is significantly more effective than project aid. The analysis of state budgeting in Section IV clarifies reasons for these important differences.

B. Narrative Results: Table 3 also presents estimates for the impact on GDP of total federal aid per capita $(\triangle \mathrm{A})$ and then federal project aid per capita $(\triangle \mathrm{AP})$ identified using the narrative record of policy innovations. Estimates are from a four variable SVAR ordering narrative aid innovations first, followed by federal net revenues exclusive of federal aid, federal government purchases, and GDP. The estimated multipliers for the narrative innovations in total federal aid ( $\triangle \mathrm{A})$ are slightly 
larger than the multipliers for total federal aid (A) identified from the initial four variable SVAR; compare Table 2, column (7) to Table 3, column (5). The 16 narrative events for project aid alone $(\triangle \mathrm{AP}$ ) provide a more precise estimate of the effect of AP on GDP; compare Table 3, columns (3) and (6). The narrative estimates for project aid are larger than those for project aid using the SVAR identification strategy, and here the estimates are statistically significant. Both narrative estimates have peak multiplier effects of 1.0 and show the initial increase in federal aid continues to stimulate GDP growth for two years after the policy innovation.

C. Robustness: Table 4 examines the sensitivity of these core results to alternative model specifications and sample periods. Only the results for federal aid are reported here. ${ }^{21}$ The central results from Table 3 remain intact. Table 4, columns (1) and (2) gives estimates from the SVAR replacing the Blanchard-Perotti specification for the contemporaneous impact of GDP on federal net revenues of $\alpha_{\mathrm{r}, \mathrm{y}}=2.08$ with the alternative estimate of $\alpha_{\mathrm{r}, \mathrm{y}}=3.00$ provided by Mertens and Ravn (2013). Mertens and Ravn show that with this alternative specification the SVAR estimates for the tax multipliers align very closely with the estimates obtained from the narrative approach used by Romer and Romer. With this adjustment our estimates for the AP and AW multipliers are smaller than those reported in Table 3. The negative impact multiplier for AP assistance remains, as do the relatively larger effects of AW over AP.22

Table 4, columns (3) and (4) extend the original five equation SVAR for fiscal policy to now allow for possible confounding effects of monetary policy; see Rossi and Zubairy (2011). We do so by adding the federal funds rate and the inflation rate as measures of monetary policy, ordered after the four fiscal variables (R, G, AW, and AP) and GDP. With the exception of the federal funds rate and the inflation rate, all variables are measured in logs. Compared to the results in Table 3, the estimated effects of AP and AW on GDP are again smaller, particularly so for AP. AW's multipliers fall to a range of 1.5 to 2.0 and remain significant to Q6; AP’s multipliers are now no larger than .3

\footnotetext{
${ }^{21}$ The multipliers for federal net revenues and federal government purchases are very similar to those reported in Tables 2 and 3.

${ }^{22}$ We have also reestimated the core SVAR model setting $\alpha_{\mathrm{r}, \mathrm{y}}=1.6$ estimated by Follette and Lutz (2010). With this specification, the peak multipliers for AW is now 2.89, occurring in Q2, and that for AP is .967, also occurring in Q2. Here too we see a statistically significant, negative impact multiplier (= . -.139) for AP aid. AW aid has a statistically significant effect on GDP into Q12 (= 1.2) while AP aid has a significant effect until Q8 (= .89).
} 
and statistically insignificant. Column (5) adds the federal funds rate and the inflation rate to the narrative specification, again ordering monetary policy after fiscal policy. The narrative aid variable remains significant through Q4. Again, the impact of fiscal policy is reduced with the inclusion of monetary policy. These results mirror those in Rossi and Zubairy (2011; Figures 9 and 11). Monetary policy is less than fully accommodating to fiscal policy.

Table 4, columns (6) and (7) report results from reestimating the SVAR after altering the assumed order by which Congress sets spending policies. The original specification assumed federal government purchases predetermine aid policies $\left(\beta_{\mathrm{g}, \mathrm{ap}}=\beta_{\mathrm{g}, \mathrm{aw}}=0 ; \beta_{\mathrm{aw}, \mathrm{g}} \neq 0 ; \beta_{\mathrm{ap}, \mathrm{g}} \neq 0\right)$. Now we reverse that ordering and allow federal aid policies to predetermine federal purchases $\left(\beta_{\mathrm{aw}, \mathrm{g}}=0 ; \beta_{\mathrm{ap}, \mathrm{g}}\right.$ $=0 ; \beta_{\mathrm{g}, \mathrm{ap}} \neq 0, \beta_{\mathrm{g}, \mathrm{aw}} \neq 0$ ). Within federal aid, AP now predetermines AW. With this revised ordering, AP assistance is estimated to have no positive effects on GDP. The estimated impacts of AW aid on GDP remain, however.

Finally, Table 4, columns (8) and (9) report estimates for the original five variable SVAR, but now for the restricted sample from 1960:Q1 to 1998:Q3, the last quarter before states were aware of the very large settlement agreement with US tobacco companies. These tobacco payments are the largest single infusion of new outside revenues into the SL sector, more than four times larger than ARRA in present value terms. To be sure that this one very large event was not unduly influencing our estimates of aid's impact, the model was reestimated for the pre-event sample. The negative impact effect of AP aid in Q1 remains. AP multipliers after Q1 are larger (but still statistically insignificant), as might be expected when a large, positive outlier event is dropped from the estimation. AW multipliers are unaffected.

D. Summary: The prudent conclusion from this analysis is to assign a significant GDP multiplier of 1.5 to perhaps 2.0 for innovations in welfare aid (AW) and to assign a smaller GDP multiplier to project aid (AP). The AP multipliers are never statistically significant using the SVAR identification and range from .4 to 1.0 using the narrative identification strategy. Between the two forms of federal assistance, AW aid appears to be the more effective policy instrument for stimulating the macroeconomy in times of recession. In the next section we estimate a behavioral model of state government budgeting to help us understand the different impacts of these two forms of federal aid on GDP. 


\section{States as Agents}

In federal public economies and in unitary systems with independently elected local officials, lower-tier governments are often the primary providers of nondefense public services. As such, they control a significant fraction of aggregate government spending and often raise significant levels of their own revenues. In the US, for example, state and local governments directly allocate 43 percent of nondefense public goods and services, raise 50 percent of aggregate government taxation, and through welfare spending and Medicaid allocate 20 percent of the aggregate government income transfer budget. Influencing the fiscal choices of these lower-tier governments can therefore provide an important policy lever for stimulating GDP growth in times of recessions. The primary policy tools for doing so in federal public economies are intergovernmental transfers using price and income incentives. Section III has presented evidence that such transfers impact the private economy. But how? Understanding the behavioral responses of lower-tier governments to intergovernmental aid provides the answer. Project aid (AP) uses weak incentives and is targeted at government purchases; welfare aid (AW) uses strong incentives and is targeted at tax relief and transfers to lower-income households.

A. Specification and Identification: We estimate state responses to federal intergovernmental transfers, specified either as lump-sum (income) project aid or matching (price) welfare aid, for the 48 mainland states for the years 1979 to 2010. We do so within a fully specified budgetary framework that accounts for all state spending and all state revenues, following the methodology in Bohn and Inman (1996). ${ }^{23}$ The state budget identity is specified as:

$$
\begin{gathered}
\mathrm{AP}+(\mathrm{rs}-\mathrm{b})-(\mathrm{gs}+\mathrm{k}) \equiv \mathrm{SURPLUS}=\Delta \mathrm{c}-\Delta \mathrm{d}+\Delta \mathrm{f} \\
(\$ 504)+(\$ 3063-\$ 276)-(\$ 3003+\$ 312) \equiv(-\$ 24)=(\$ 81)-(\$ 55)+(-\$ 50),
\end{gathered}
$$

where:

$\mathrm{AP}=$ State project aid per person defined as all exogenous federal aid to states including general revenue-sharing, federal aid for education, federal highway and transportation aid, annual payments under the 1998 Tobacco Settlement, and federal aid (other than Medicaid

23 Budgetary data for the analysis are from the Census of Governments, State Government Finances, various years. While the budget identity can be specified for the years back to 1947, our analysis is restricted to the 1979-2010 period because of our choice of explanatory variables, one of which is unexpected shocks to state unemployment rates that are measured only from 1976 onward. In addition, we allow for an AR(1) process to our error structure. 
assistance) paid under the American Reinvestment and Recovery Act;

rs $=\quad$ State revenues per person defined as all state taxes plus charges and fees plus miscellaneous revenues plus profits from state-run utilities plus profits from state liquor stores plus net proceeds from lottery sales;

$\mathrm{b}=\quad$ State own expenditures per person for welfare and medical assistance defined as aggregate state expenditures (B) minus federal aid for welfare and Medicaid ( $\mathrm{AW}=\mathrm{m} \bullet \mathrm{B}$, where $\mathrm{m}$ is the federal matching rate for welfare and Medicaid spending: $\mathrm{b}=(1-\mathrm{m}) \bullet \mathrm{B})$;

gs $=$ State expenditures per person for current operations plus intergovernmental assistance paid to local governments plus interest on state debt plus state own contributions to state public employee retirement, workers' compensation, and unemployment trust funds (but excluding welfare and Medicaid spending);

$\mathrm{k}=\quad$ Total capital outlays per person;

$\Delta \mathrm{c}=$ Changes in cash and security holdings per person, other than in insurance trust funds;

$\Delta \mathrm{d}=$ Changes in short- and long-term debt outstanding per person; and

$\Delta \mathrm{f} \equiv$ Changes in contributions per person to insurance trust funds (including pensions) specified as $\Delta \mathrm{f} \equiv$ SURPLUS $-\Delta \mathrm{c}+\Delta \mathrm{d}$.

Sample means are reported below for each of the fiscal variables within the budget identity, measured as real (2005) dollars per person. Contributions to the trust fund $(\Delta f)$ are treated as a residual category to ensure adding up in our specification of the state budgetary accounts. ${ }^{24}$ State project aid (AP) specified here has been defined to correspond to the same federal aid programs used to define project aid in our aggregate analysis.

The LHS of equation (4) reports all revenues received by the state less all spending by the

\footnotetext{
${ }^{24}$ We have chosen changes in the stock of insurance trust fund assets $(\Delta \mathrm{f})$ as our "residual" category to ensure cash flow balance. The Census of Governments' measures of holdings in insurance trust funds combine an unknown mix of short- and long-term assets measured at market and book values. Thus a measure of $\Delta \mathrm{f}$ computed directly from changes in Census estimates of holdings will be very noisy, both over time and across states. Fortunately, this is not as serious a problem for noninsurance cash and security holdings as those assets are typically held for short horizons. Our residual measure of $\Delta \mathrm{f}$ should be interpreted as cash moved into, or out of, the insurance trust funds required to balance overall fiscal activities of the state in any fiscal year.
} 
state. The difference defines the cash flow surplus ( SURPLUS $>0$ ) or deficit (SURPLUS $<0$ ) in each fiscal year. Over our sample period, the average SURPLUS indicates a small deficit of -\$24 per person, but the standard deviation of SURPLUS is \$263. We cannot reject the null hypothesis that the states in our sample have run a balanced budget, on average, over the period 1979 to $2010{ }^{25}$ The RHS of equation (4) shows where the dollars go when there is a positive cash flow, or where the dollars come from when there is a negative cash flow. When there is a positive cash flow (surplus), the extra funds can be saved in noninsurance savings accounts $(\Delta c>0$ : "rainy day" funds or bond "sinking” funds), used to repay outstanding short- and long-term debt $(\Delta \mathrm{d}<0)$ or put into insurance trust funds ( $\Delta \mathrm{f}>0$ : pension, workers' compensation, unemployment benefit trust funds). When there is a negative cash flow (deficit), then funds must be withdrawn from the savings accounts $(\Delta \mathrm{c}<0$, $\Delta \mathrm{f}<0)$ or short- or long-term government debt must be increased $(\Delta \mathrm{d}>0)$. Over all the states and years in our sample, there is a small average deficit paid for by increased government debt and withdrawals from the insurance trust funds. ${ }^{26}$

To understand how states allocate an extra dollar of project aid or welfare aid across rs, b, gs, $\mathrm{k}, \Delta \mathrm{c}, \Delta \mathrm{d}$, and $\Delta \mathrm{f}$, we specify and estimate a behavioral budget model of state finances, specified generally as:

$$
(\mathrm{rs}, \mathrm{b}, \mathrm{gs}, \mathrm{k}, \Delta \mathrm{c}, \Delta \mathrm{d}, \Delta \mathrm{f})=f\left(\mathrm{AP}, 1-\mathrm{m} ; \mathrm{I}, \tilde{\mathrm{u}} ; \mathrm{c}_{-1} ; \mathbf{X}\right)+\mathrm{v}_{\mathrm{s}}+\mathrm{v}_{\mathrm{t}}+\mathrm{v}_{\mathrm{st}},
$$

where each of the state fiscal choices is determined by a common set of federal policies (project aid, AP, and matching aid for welfare and Medicaid, 1-m), the state’s economic environment (mean household income, I, and unanticipated shocks to the state's unemployment rate, ũ), the state’s lagged savings wealth $\left(\mathrm{C}_{-1}\right)$, and a set $(\mathbf{X})$ of political, institutional, economic, and natural disaster controls.

25 This is not to say that every year has been in average balance or that every state is in balance over time. For example, the average value of SURPLUS in fiscal years of the Great Recession was -\$171/person in FY 2009 and \$105/person in FY 2010. In non-recession years, however, average SURPLUS is typically positive, ranging from as small as \$3/person in FY1996 to \$107/person in FY2006. For average variation across the states, see Bohn and Inman (1996).

${ }^{26}$ One should not make too much of these average changes in the savings and debt accounts. First, all standard deviations for these changes are far larger than their sample means. Second, having positive increases in state debt is not a problem if those increases are allocated to pay for capital outlays; on average (and assuming fungibility) this is the case as $\mathrm{k}(=\$ 312)>\Delta \mathrm{d}(=\$ 55)$. Third, contributions to state insurance trust funds, importantly pension funds, are already accounted for in state government spending (gs). Whether those contributions are sufficient to fully fund state pensions is another matter, but not at issue in this study. Withdrawals from insurance trust fund accounts as supplementary payments for one-time pension COLA payments or UE benefits are not uncommon. 
The estimated budget equations also control for common shocks affecting all state budgets in any one year (e.g., interest rate changes, federal tax reforms) using year fixed effects $\left(v_{t}\right)$ and unchanging state-specific institutions (e.g., balanced budget rules), politics, and economic fundamentals affecting budgetary outcomes using state fixed effects $\left(v_{s}\right)$. Estimation is by generalized least squares. The within-year and state error terms $\left(v_{\mathrm{st}}\right)$ allow for state-specific autocorrelation following an AR(1) process and heteroskedasticity across states. No spatial autocorrelation is assumed, however.

To control for year-to-year changes within the state in important determinants of fiscal choices - particularly those potentially correlated with federal policies - we include in $\mathbf{X}$ (i) political controls: the state's vote for the Republican candidate in the last presidential election, the Berry et al. (2010) measure of conservative-liberal preferences of state residents, and whether the budget is set in the year preceding the election of a governor; (ii) an institutional control: the adoption and then presence of a requirement for contributions to a state rainy day fund; (iii) additional economic controls: a state-specific consumer price index, national oil price shocks interacted with whether the state is an energy- producing or energy-consuming state, and unexpected shocks to federal defense spending within the state; and (iv) a control for natural disasters: the total economic damages from disasters lagged one year. Equation (5) is specified as a linear expenditure system, imposing an adding-up constraint for the impact of each variable on fiscal outcomes.

Key to identifying the effects of federal intergovernmental transfers on state fiscal choices is the assumption that those transfers as measured here are uncorrelated with the unmeasured $\left(v_{\mathrm{st}}\right)$ determinants of state revenues, spending, and savings decisions. We seek to establish the appropriateness of this assumption by three specification strategies. First, care is taken to ensure that federal aid is specified to include only those transfers exogenous to each state's current period budget. This will not be the case for total welfare and Medicaid aid specified as a federal matching subsidy at a rate $m$ per dollar of state welfare spending $(B)$ : $A W=m \bullet B$. Unmeasured shocks to $B$ will be correlated with AW, biasing the estimate of AW's impact on state fiscal outcomes. To remove this source of endogeneity, we estimate the effect not of AW but of $(1-\mathrm{m})$ on fiscal outcomes, where $(1-\mathrm{m})$ is exogenous to current state budget choices and can be interpreted as the 
"net price" of each dollar of state spending on welfare services. ${ }^{27}$ Consistent with the budget identity, the dependent variable for welfare spending will be own state spending for welfare services: $\mathrm{b}=(1-\mathrm{m}) \cdot \mathrm{B}$.

Second, project aid (AP) is specified to include only those programs whose support is, by design or administration, independent of current-period state spending. This specification includes all funding for public education, state transportation infrastructures, jobs and training, general revenue sharing, and as part of the 1996 reform of welfare financing all federal aid to support income transfers to lower-income households (known as Temporary Assistance for Needy Families, or TANF). ${ }^{28}$ Finally, we include in AP the payments to states under the 1998 Master's Settlement Agreement with US tobacco companies as de facto federal project aid; in fact, the settlement was motivated to a significant degree by a congressional threat to legislate such transfers. Evidence on the fungibility of such assistance across all budget allocations allows us to aggregate federal support under all these programs into a single transfer to states; see Craig and Inman (1982) and Conley and Dupor (2013) for federal aid and Singhal (2008) for tobacco settlement payments.

Third, even after controlling for the endogeneity of aid because of legislative design, there remains the possibility that special events within the state in a given year might motivate Congress or the bureaucracy to offer, or take away, federal aid, and that these special circumstances might also influence state budget choices. A natural disaster such as Hurricane Katrina seems one obvious candidate. If so, failing to control for such events will bias our coefficient estimates of aid's effects on budgets. The bias seems most likely to affect our estimates for AP. Efforts to find compelling instrumental variables for such assistance, those with an $F$ statistic near or exceeding the usual

\footnotetext{
${ }^{27}$ The federal matching rate for welfare and Medicaid expenditures, m, known officially as the Federal Medical Assistance Percentage, is set each year based upon the state's three-year average income relative to the national average income beginning five years before the rate applies - e.g., the matching rate that applies in 2012 is based on incomes for the years 2007 to 2009. The formula that sets $\mathrm{m}$ is quadratic in incomes. Poorer states have higher matching rates than richer states, but no state can fall below .50. The number of states at the lower bound has ranged from as few as 11 to as many as 14 over our sample period. There have been two important "policy moments" that led to significant changes in m: in FY 2004 following the Jobs and Growth Tax Relief Reconciliation Act of 2003 and in FY2009 and FY2010 following ARRA. Variation in $\mathrm{m}$ in other years turns on variation in the state's five-year lagged income performance relative to the rest of the country.

${ }^{28}$ Program details supporting the exogeneity assumption for project aid can be found in Craig and Inman (1982) for education, Knight (2002) and U.S. Department of Transportation (2007, p. 19) for transportation, Gramlich (1978) for jobs and training programs, Reischauer (1975) for general revenue-sharing, and Chernick (1998) for TANF support.
} 
threshold for "strong" instruments, proved unsuccessful, however. ${ }^{29}$ Use of weak instruments may add to, rather than reduce, bias in our estimates; see Bound, Jaeger, and Baker (1995). We therefore adopt, as our third strategy, the inclusion of the economic, political, institutional, and disaster controls included in $\mathbf{X}$ to minimize possible bias in our estimates of federal aid's effects on state budgets.

B. Results: Table 5 summarizes our results for the impact of the fiscal policy and economic variables on each of the seven budgetary aggregates. Estimates for $\Delta \mathrm{f}$ are obtained from the budget identity’s adding-up constraint. $^{30}$ Estimates for the effects of a $\$ 1$ increase in the state’s mean household income (I) show state government activities to be normal goods, even for welfare spending (b). From the first row of Table 5, state revenues (rs) rise by $\$ .024 /$ person, government current spending (gs) by \$.012/person, welfare spending (b) by \$.002/person, and capital spending (k) by $\$ .001 /$ person. This leaves a positive cash flow from the marginal increase in state revenues of \$.009/person, which is then allocated as \$.006/person to non-insurance fund savings ( $\Delta \mathrm{c}$, “rainy day”) and $\$ .004 /$ person to insurance trust fund savings $(\Delta \mathrm{f})$. There is also a $\$ .001 /$ person increase in state debt $(\Delta \mathrm{d})$, presumably to finance the $\$ .001 /$ person increase in capital spending.

It is instructive, too, to see how state finances react to an unexpected increase in state unemployment ( $\tilde{\mathrm{u}})$, particularly in light of the large surprise in state economic fortunes beginning in FY2009. The sample’s mean increase in $\tilde{\mathrm{u}}$ in 2009 was $\Delta \tilde{\mathrm{u}}=.022$. After within-fiscal-year adjustments, our results predict that state revenues would still have declined by - \$36.10/person. States are predicted to cut current spending by $-\$ 11.44 /$ person and capital spending by $-\$ 1.48 /$ person. Welfare spending would rise by $\$ 4.40$ person, however. The net result is still an end-of-fiscal-year deficit of - \$27.58/person, or about 1 percent of the state budget, covered by an increase in state debt

${ }^{29}$ We followed the approach of Knight (2002), using changes in congressional committee membership for the state's representatives, tenure of the state's congressional delegation, and state party representation relative to party majority in each chamber. In addition, we added changes in the governor's party relative to the state's majority congressional party and whether the state was a potential "swing state" based upon the closeness of the last presidential election. The resulting $F$ statistics never exceeded 4.0 for our sample period.

30 That is, $\mathrm{d}(\Delta \mathrm{f}) / \mathrm{d}(\bullet) \equiv \mathrm{d}(\mathrm{AP}) / \mathrm{d}(\bullet)+\mathrm{d}(\mathrm{rs}) / \mathrm{d}(\bullet)-[\mathrm{d}(\mathrm{b}) / \mathrm{d}(\bullet)+\mathrm{d}(\mathrm{gs}) / \mathrm{d}(\bullet)+\mathrm{d}(\mathrm{k}) / \mathrm{d}(\bullet)]-\mathrm{d}(\Delta \mathrm{c}) / \mathrm{d}(\bullet)+\mathrm{d}(\Delta \mathrm{d}) / \mathrm{d}(\bullet)$, for $\bullet=\mathrm{I}, \mathrm{AP},(1-\mathrm{m}), \mathrm{c}_{-1}$, and $\tilde{\mathrm{u}}$. The choice of $\Delta \mathrm{f}$ as the "residual" category for estimation follows from the decision to use $\Delta \mathrm{f}$ as the residual category for cash flow budgetary balance; see footnote 24 . 
of $\$ 29.44$ person. $^{31}$

Increases in state project aid (AP) have no significant effect on state revenues (rs) or welfare spending (b), but AP does increase spending on current state operations and transfers to local governments (gs) and capital outlays (k); see the second row of Table 5. Total state spending rises by $\$ .51$ for each dollar increase in AP. ${ }^{32}$ (Contrast to the spending impact of $\$ 1$ of household income of only $\$ .015$; here again, we have evidence of a flypaper effect.) The remaining $\$ .49$ of AP is net savings and equals an increase of \$.33 in the state’s rainy day fund $(\Delta c)$ and $\$ .19$ in the state’s insurance trust fund accounts $(\Delta \mathrm{f})$, offset by a $\$ .03$ increase in state debt $(\Delta \mathrm{d})$, again used to finance, in part, state capital outlays. ${ }^{33}$

Project aid that is saved is spent in subsequent years as it is withdrawn from the state's nontrust fund accounts (c), but the rate of withdrawal is very slow and the added spending effects in the near term are slight. ${ }^{34}$ A $\$ 1$ increase in the lagged value of noninsurance trust savings $\left(\mathrm{C}_{-1}\right)$ encourages the state to withdraw only \$.107 from the account each year; see the fourth row of Table 5. That $\$ .107$ is allocated $\$ .006$ to welfare spending, $\$ .059$ to current accounts spending, and \$.01 to capital outlays. Total spending rises by $\$ .075$. The remaining $\$ .036$ is used to pay down debt outstanding. (There is also a $\$ .021$ increase in state revenues that appears to go to further debt

${ }^{31}$ The estimated impacts on each budget category are computed from the results in Table 5 as $\Delta \tilde{u} \bullet d(\bullet) / d u \tilde{~}$ For example, $\Delta \mathrm{rs}=.022 \bullet(-1641)=-\$ 36.10 /$ person. From the revenue and spending impacts, we then estimate $\Delta S U R P L U S$ $=\Delta \mathrm{rs}-[\Delta \mathrm{b}+\Delta \mathrm{gs}+\Delta \mathrm{k}])=-\$ 36.10-[\$ 4.40+(-\$ 11.44+(-\$ 1.48)]=-\$ .27 .58$. The estimated impact on debt outstanding $=.022 \cdot 1338.3=\$ 29.44$.

${ }^{32}$ Leduc and Wilson (2013) find that a dollar of highway assistance under the rules of ARRA leads to larger effects on state spending, with a marginal effect of such targeted AP aid on highway spending ranging from .75 to 1.00 . For this program there was a closely monitored "maintenance of effort" provision, and payment of aid was not made until actual expenditures occurred and construction had begun. What is not known is how spending changed for close substitutes for highways construction - e.g., state support for public transportation and county roads - or, more generally, how easily other spending in our full list of AP programs can, or will, be monitored.

${ }^{33}$ We also tested for possible reallocations of AP in recession years and found no significant differences, except for a $\$ .02$ reallocation of spending from current operations (gs) to capital outlays (k). The category that was cut within current operation spending was aid to local governments; spending for state services was unaffected. Overall spending from an additional dollar of AP remained constant at \$.50, with the remaining $\$ .50$ saved in rainy day and trust fund accounts as reported in Table 5.

34 We assume that withdrawals are done only from the noninsurance, or rainy day, fund; see National Association of State Budget Officers, Fiscal Survey of the States, (various years), Chapter 3: Total Balances. Savings in the insurance trust fund accounts are held for specific events such as payments to unemployed or injured private sector workers or for retirement benefits of state employees. 
reductions and to contributions to the trust fund accounts. Exactly why an increase in cash holdings might "motivate" such behavior is unclear, but its net effects on state spending are negligible.) From these estimates, the final spending effects of a \$1 increase in AP will be \$.506 in the year aid is received and only $\$ .02$ in each year thereafter. ${ }^{35}$

Increases in welfare aid (AW) are made by increasing the federal rate (m) for income transfers paid as aid to families with dependent children (AFDC, until the 1997 reforms) and health care outlays for lower-income households (Medicaid). A state's own expenditures (b) will equal qualified welfare spending $(B)$ less welfare aid $(A W=m \bullet B): b=(1-m) \bullet B$. The variable $(1-m)$ is the "net price" of welfare spending and B is the aggregate spending for welfare services for lower-income families. The elasticity of $\mathrm{b}$ and $\mathrm{B}$ with respect to $(1-\mathrm{m})$ can be specified as $\varepsilon_{\mathrm{b},(1-\mathrm{m})}=1+\varepsilon_{\mathrm{B},(1-\mathrm{m})}$. Based upon the results in Table 5 , the estimated elasticities evaluated at the sample means are $\varepsilon_{\mathrm{b},(1-\mathrm{m})}$ $=.57$ and $\varepsilon_{\mathrm{B},(1-\mathrm{m})}=-$. 43. Increasing the matching rate lowers the net price for welfare spending and lowers own spending by the state, but increases aggregate spending going to poor households. This was the approach adopted by ARRA, which increased the matching rate from an average of .60 in FY2008 to .70 for FY2009-2011.

From row three of Table 5, a .10 rise in the federal matching rate $(\mathrm{m})$ lowers the average net price $(1-\mathrm{m})$ from .4 to .3 , then leads to lower own welfare spending of $-\$ 40.59 /$ person and, from cross-price effects, to a fall in spending on government services of $-\$ 45.70$ and in capital outlays of -\$7.57. Together, total government spending declines by $\mathbf{\$} \$ 93.86$. This savings is first allocated to lower taxes for the middle class, which decline by $-\$ 52.58$. The remaining $\$ 41.28$ is then allocated to increase the rainy day fund by $\$ .70$, to pay down outstanding debt by $\$ 15.29$, and to increase savings in insurance trust funds by $\$ 25.30$. Transfers and services received by poor households are higher because of the increase in $m$ and can be estimated from changes in own welfare spending. For a .10 rise in the matching rate, evaluated at sample means, total support for poor households (B) rises

35 The year after the receipt of aid, there is a $\$ .326$ increase in cash savings. This $\$ .326$ increase is withdrawn at the rate of -.107 per dollar or by $-\$ .035(=-.107 \cdot .326)$ in the next fiscal year. This $\$ .035$ withdrawal is then allocated as $\$ .025$ to increased spending and $\$ .01$ to paying down of debt. This leaves $\$ .291$ ( $=.326$ - .035) in the cash account, which allows for another withdrawal of $-\$ .031(=-.107 \cdot .291)$ allocated as $\$ .022$ to spending in the third year after the receipt of aid. The sequence is repeated again in year four and thereafter. The final equilibrium increase in aggregate state spending will be about $\$ .75$ per dollar of AP assistance, with $\$ .506$ occurring in the year the aid is received. 
by $\$ 95 /$ person, or, assuming a national poverty rate of 12 percent, by $\$ 792$ per poor person. ${ }^{36}$

The rise in state welfare spending and the higher federal matching rate mean increased federal aid to state governments for welfare spending, that is, AW rises. For a .10 rise in m, and again evaluated at sample means, $\Delta \mathrm{AW}=\$ 135$ /person. How is $\Delta \mathrm{AW}$ spent? The typical state allocates \$95/person to lower-income households and the remaining \$40/person, along with the cuts in spending, to pay for the fall in middle-class taxes, increased savings, and debt retirement.

C. Implied Macro Multipliers: Just as microeconometric estimates of consumer and firm behavior provide plausible bounds on estimated macroeconomic tax and spending multipliers, so too can estimates of state government behavior bound our estimates for the macroeconomic effects of federal AP and AW assistance. Each form of assistance has three effects on state budgetary behaviors: on taxes net of transfers $(\mathrm{R}=\mathrm{rs}-\mathrm{B})$, on government purchases $(\mathrm{G}=\mathrm{gs}+\mathrm{k})$, and on changes in public wealth $(\Delta \mathrm{W}=\Delta \mathrm{c}-\Delta \mathrm{d}+\Delta \mathrm{f})$. Each budgetary effect has a potential multiplier impact on the private economy.

For AP, the implied multiplier from state behavior is:

$$
\mathrm{dGDP} / \mathrm{dAP}=(\mathrm{dGDP} / \mathrm{dR}) \bullet[\mathrm{dR} / \mathrm{dAP}]+(\mathrm{dGDP} / \mathrm{dG}) \bullet[\mathrm{dG} / \mathrm{dAP}]+[\mathrm{dGDP} / \mathrm{dW}) \bullet[\mathrm{dW} / \mathrm{dAP}],
$$
where $\mathrm{dR} / \mathrm{dAP}=-.015, \mathrm{dG} / \mathrm{dAP}=.506$, and $\mathrm{dW} / \mathrm{dAP}=.488$ from Table $5 .{ }^{37}$ Our results in Table 3 provide estimates of the multipliers for net revenues and government purchases for our sample period: $\mathrm{dGDP} / \mathrm{dR}=-3.189$ and $\mathrm{dGDP} / \mathrm{dG}=.884$ after four quarters or one fiscal year. The multiplier for an increase in public wealth might be approximated by the real interest rate (.03) times the (positive, assuming eventual tax relief) value of the net revenue multiplier: $\mathrm{dGDP} / \mathrm{dW}=(3.189 \bullet 03)$ $=.096$. If so, then upon substitution a micro-behavior estimate of the four quarter AP multiplier would be $\mathrm{dGDP} / \mathrm{dAP}=.55$, comfortably within the 95 percent confidence intervals for all our macro estimates.

${ }^{36}$ Own welfare spending is defined as $\mathrm{b}=(1-\mathrm{m}) \cdot \mathrm{B}$, where $\mathrm{B}$ is transfers to poor households. At sample means, $\mathrm{m}=.6$, and $\mathrm{b}=\$ 276$, so $\mathrm{B}=\$ 690$ /person. After $\mathrm{m}$ is increased to $.7, \mathrm{~b}=\$ 276-\$ 40.59=\$ 235.41$. At the new levels, $\mathrm{m}=.7$ and $\mathrm{b}=\$ 235$, then $\mathrm{B}=\$ 785$. The implied increase in total lower-income transfers per person is therefore $\Delta \mathrm{B}$ $=\$ 785-\$ 690=\$ 95 /$ person.

37 From estimates in Table 5, the effect on net revenues (R) will be the -.000 effect on aggregate revenues (rs) minus the increase in benefits (B) paid to poor households, which will equal $\Delta \mathrm{b} /(1-\mathrm{m})$, or $.006 / .4=.015$. The effect on government purchases $(\mathrm{G})$ will equal $\Delta \mathrm{gs}+\Delta \mathrm{k}=.379+.127=.506$. The effect on public wealth (W) will equal $(\Delta \mathrm{c}-$ $\Delta \mathrm{d}+\Delta \mathrm{f})=.488$. 
For AW, the implied multiplier is:

$\mathrm{dGDP} / \mathrm{dAW}=(\mathrm{dGDP} / \mathrm{dR}) \cdot[\mathrm{dR} / \mathrm{dAW}]+(\mathrm{dGDP} / \mathrm{dG}) \cdot[\mathrm{dG} / \mathrm{dAW}]+[\mathrm{dGDP} / \mathrm{dW}) \cdot[\mathrm{dW} / \mathrm{dAW}]$,

where the effects of AW on net revenues, government purchases, and wealth are the coincident changes in $\mathrm{R}, \mathrm{G}$, and $\mathrm{W}$ and then $\mathrm{AW}$ estimated from changes in the federal matching rate (m). Evaluated at sample means, $\mathrm{dR} / \mathrm{dAW}=-1.09, \mathrm{dG} / \mathrm{dAW}=-.395$, and $\mathrm{dW} / \mathrm{dAW}=.31 .^{38}$ The negative impact of AW on G, also observed in Taylor's (2011) time series analysis, arises because of the positive cross-price effects of $(1-\mathrm{m})$ on government purchases and the fact that AW increases as $\mathrm{m}$ rises and $(1-\mathrm{m})$ declines. Again assuming four quarter multipliers of dGDP/dR = -3.189, dGDP/dG $=.884$, and $\mathrm{dGDP} / \mathrm{dW}=.096$, the implied four quarter multiplier for $\mathrm{AW}$ is 3.16. This estimate is higher than those reported in Tables 3 and 4, where the four quarter AW multipliers range from 1.5 to 2.1, but consistent with the large employment effects estimated by Chodorow-Reich et al. (2012) in their analysis of ARRA's .10 average increase in the matching rate. ${ }^{39}$

The important point here is not that we can replicate exactly our macro estimates from state fiscal behaviors, but rather that the observed state behaviors help us understand the estimated macro effect, and, in particular, the policy superiority of welfare aid over project aid as a way to stimulate the aggregate economy. AW is preferred to AP for two reasons. First, AW aid is paid as a price subsidy encouraging significant increases in transfers to poor households and in tax relief for middleclass households. Further, AW is paid only when the state pays transfers or gives tax relief. In contrast, AP is paid as a fungible income grant to states, and states save about half the grant, releasing

38 These marginal effects are based upon the effects of an increase in $\mathrm{m}$ of .10, evaluated at sample means, where (from text above) $\Delta \mathrm{R}=\Delta \mathrm{rs}-\Delta \mathrm{B}=-52.58$ - $95=-147.58 ; \Delta \mathrm{G}=\Delta \mathrm{gs}+\Delta \mathrm{k}=(-45.70)+(-7.57)=-53.27$; and $\Delta \mathrm{W}$ $=\Delta \mathrm{c}-\Delta \mathrm{d}+\Delta \mathrm{f}=.70-(-15.29)+25.30=41.29$. The implied change in $\mathrm{AW}$ is $\Delta \mathrm{AW}=135$. The resulting estimates are $\mathrm{dR} / \mathrm{dAW}=-147.58 / 135=-1.09 ; \mathrm{dG} / \mathrm{dAW}=-53.27 / 135=-.39 ;$ and $\mathrm{dW} / \mathrm{dAW}=41.29 / 135=.31$.

39 The primary reason for the larger estimate here is our assumption that increased spending on lower-income services - in particular, Medicaid services - has the same household spending consequences as transfers of income. This will be true only if poor households receive all of new Medicaid funding in added services and spend on health care exactly what increased Medicaid service provides. This is unlikely. Additional aid does expand Medicaid roles, and once uncovered households are now insured. But how changes in this coverage impact household consumption seems an open question. One estimate can be inferred from the work of Finkelstein et al. (2012), who estimate that persons randomly selected to join Oregon's Medicaid program incurred an additional \$788/person health care expense above that incurred by the non-selected controls (Table V) and saved \$390/person in own expenses (Table VII). Assuming that Medicaid paid all of the additional medical expenses, these results suggest that about half of every dollar of Medicaid spending becomes new income to Medicaid recipients. Assuming that \$.50 of each dollar of new Medicaid spending, rather than the full dollar, becomes added income, then dGDP/dAW falls to 1.68 and within the range of estimates reported in Tables 3 and 4. 
saved funds only slowly in later budgets. Our panel estimates confirm the aggregate time series results of Gramlich (1978) and Taylor (2011). Second, AW is paid to lower income households and middle-class taxpayers as additional income. When spent, AP raises government purchases. The consensus conclusion, confirmed by our results, is that the estimated macroeconomic multiplier for tax and transfer relief is significantly larger, perhaps two to three times larger, than the multiplier for government purchases.

\section{ARRA as Fiscal Stimulus}

The American Recovery and Reinvestment Act (ARRA) has now spent \$796 billion with the hopes of stimulating the US economy onto a path of sustained economic growth after the greatest recession since the 1930s. We use an estimated version of the five variable SVAR of equation (3) to evaluate the impact of this legislation on GDP growth. The five variable SVAR allows us to include both project aid (AP) and welfare aid (AW) as part of the policy evaluation. For purposes of the evaluation we have reestimated the SVAR for the pre-ARRA sample period 1960:1 to 2009:1. Based on these estimates, we then simulate the performance of the economy without, and then with, ARRA policy innovations. ${ }^{40}$ Table 6 summarizes our results.

We specify the timing and size of ARRA's fiscal innovations following Romer and Romer (2010). For ARRA innovations in federal net revenues we use the total tax savings and direct transfers to households and firms that occurred in the first quarter after the passage of ARRA: $\Delta \mathrm{R}=$

40 Simulations for the path of GDP following the fiscal innovations are calculated in four steps. First, each policy innovation is transformed into a corresponding structural shock for the five variable specification of equation (3) denoted as $\left(\mathrm{v}_{\mathrm{t}}^{\mathrm{r}}, \mathrm{v}_{\mathrm{t}}^{\mathrm{g}}, \mathrm{v}^{\mathrm{ap}}{ }_{\mathrm{t}}, \mathrm{v}^{\mathrm{aw}}\right)$, where shocks are the percentage change from the quarter preceding the innovation. Second, estimated and pre-assigned values of the $\beta$ 's from the SVAR analysis are then used to provide vectors of the seasonally adjusted reduced form fiscal shocks $\left(u^{\mathrm{C}}\right)$ for each year $(\mathrm{t})$. Third, given $u^{\mathrm{C}}$, the estimated and pre-assigned values of the $\alpha$ 's are used to solve for the reduced form fiscal shocks associated with each innovation. Finally, the reduced form fiscal shocks and the originally estimated VAR specified by eq. (1) with the control variable "deep recession" set equal to 1 are used to provide a projected path for GDP following each fiscal innovation, first individually (Table 6, columns (2)-(5)) and then for all four ARRA innovations together (Table 6, column (6)). The predicted path of GDP without ARRA innovations is also provided (Table 6, column (1)) as a benchmark for evaluating the impact of ARRA policies. All reported estimates of the incremental effects of policy on GDP are computed as the difference between the predicted path of GDP with and without the innovation. We have also simulated the performance of ARRA using a reestimated seven variable SVAR including the federal funds rate and the inflation rate as two additional endogenous variables to control for the role of monetary policy. As reported in Table 4, the simulated impacts of fiscal policy on growth are from 5 to 10 percent less with monetary controls included but do not affect any of our substantive conclusions. The simulation results for this alternative specification are available upon request. 
$\$ 45.2$ billion in 2009:2. ${ }^{41}$ For government purchases, we assign the innovation to the quarter when actual purchases are first observed, with the level of the innovation equal to purchases in that quarter: $\Delta \mathrm{G}=\$ 11.83$ billion in 2010:1. The lag of almost a year between the passage of ARRA and the actual receipt of funds by the private economy reflects the time between application, application approval, and receipt of funding for the programs included in the spending innovation. ${ }^{42}$ Innovations in SL project aid include additional funding for three existing federal aid programs: aid to K-12 education (called "stability" aid), aid for infrastructure spending for roads and bridges, and aid for construction of public housing. Education assistance was paid immediately in 2009:2 and this innovation was assigned the actual allocation in that period: $\triangle \mathrm{AP}=\$ 8.686$ billion. Significant funding for the infrastructure projects and public housing was not observed until 2010:1 but then equaled $\Delta \mathrm{AP}=$ $\$ 18.753$ billion. Finally, the innovation for welfare aid included added support for SL spending for family services, child support, low-income housing allowances, and Medicaid and was first paid in 2009:2 at a level of $\Delta \mathrm{AW}=\$ 37.032$ billion. $^{43}$

The most effective of the individual ARRA policies is direct tax relief $(\Delta \mathrm{T})$; see Table 6 , column (2). ARRA's innovation in tax relief is estimated to increase GDP by $\$ 659 /$ person at its peak in 2009:4; this is an increase in GDP growth above the no-policy baseline of approximately 1.6 percent. Tax relief continues to have a significant positive impact on GDP growth for at least two years after the innovation. The strong impact of tax policy is due to the relatively large estimated

\footnotetext{
${ }^{41}$ Source: www.recovery.gov/News/featured/pages/TaxReliefDec2010.aspx.
}

${ }^{42}$ The most important programs included in $\Delta \mathrm{G}$ are direct federal expenditures for rural water and waste disposal, energy efficiency and renewable resources, and science and health funding. For these programs we have detailed data on the timing of spending. However, there are smaller initiatives for which detailed funding is not available. The larger programs for which data on timing are available equal 37.7 percent of all proposed $\Delta \mathrm{G}$ spending. We assume the timing for all other, smaller programs matched that in the waste disposal, energy, and science initiatives. We therefore inflated the total spending in 2010:1 in these measured programs by $2.6(=1 / .377)$. Total measured spending in 2010:1 equaled $\$ 4.464$ billion and (estimated) spending for all $\Delta \mathrm{G}$ programs equaled $\$ 11.83$ billion. Source: www.recovery.gov/Transparency/Agency/reporting/agency.aspx.

43 Full information on the timing of stability aid payments is available; $\$ 8.69$ billion was paid in 2009:Q2. For project aid, full information is available for highway aid and for housing aid. What is missing is information on the many small project grants for job training, constituting about 26 percent of all proposed project aid in ARRA. Highway and housing aid for which we do have timing data equal 74 percent of all project aid. We therefore adjust measured project aid spending of $\$ 13.80$ billion upward by $1.3589(=1 / .74)$ for a total of $\$ 18.753$ billion. The actual payments and timing for Medicaid are reported, while funding for the many smaller programs are not. Medicaid constitutes 83 percent of total budgeted ARRA funding for AW assistance. We therefore adjusted the actual Medicaid allocation in 2009:Q2 of $\$ 30.85$.billion upward by 1.2 (= 1/.833) for a total AW innovation at this date of $\$ 37.03$ billion.

Source: www.recovery.gov/Transparency/Agency/reporting/agency.aspx. 
multipliers for tax relief and the significant size of the innovation within ARRA.

Also estimated to have a strong effect on GDP growth is ARRA's innovation in welfare aid $(\Delta \mathrm{AW}$ ); see Table 6, column (5). The estimated increase in GDP is $\$ 147 /$ person at its peak in 2009:4; this is an increase in GDP growth above the no-policy baseline of 3/10s of 1 percent. The $\triangle \mathrm{AW}$ innovation continues to have a significant effect on GDP growth for another year. Again, the relatively large multiplier effects for AW, coupled with the relatively large innovation for such assistance, explain its significant impact on GDP growth.

Least effective of the ARRA policies, largely because of their relatively small multiplier effects, are direct federal purchases $(\Delta G)$ and project aid $(\Delta A P)$. The estimated maximal impact for federal purchases is only \$23/person in the first quarter of the innovation, while that for project aid is \$38/person in 2010:3; see Table 6, columns (3) and (4), respectively. The small estimated multipliers for both policies explain their modest impacts. ${ }^{44}$

Table 6, column (6) shows the estimated impact on growth of all four ARRA policies working in unison. As a package, ARRA's estimated maximal impact is \$823/person, occurring in 2009:4. The innovations in government spending and project aid in 2010:1 provide a modest additional stimulus to that available from (now declining) tax and tax-transfer policies. The maximal impact of ARRA on GDP growth is 1.8 percent.

Finally, we provide estimates for the impact of an alternative, "improved” policy strategy for ARRA funding; see Table 6, column (7). Under the improved policy, all of the federal spending $(\Delta \mathrm{G})$ innovation is reallocated to the innovation in $\Delta \mathrm{T}(=\$ 57.03$ b. $=\$ 45.2$ b. $+\$ 11.83$ b. $)$ in 2009:2, and all of the project aid ( $\triangle \mathrm{AP})$ innovation is reallocated to the innovation in $\triangle \mathrm{AW}(=\$ 64.473 \mathrm{~b} .=$ \$37.03 b. $+\$ 8.69$ b. $+\$ 18.753$ b.), also in 2009:2. Peak GDP growth again occurs in 2009:4 but now equals \$1094/person implying an 2.6 percent improvement in GDP over the no-policy benchmark; see Table 7, column (7). The improved policy package increases the overall effectiveness of the original ARRA allocations by approximately 30 percent in each of the quarters following the

44 This conclusion was appreciated by important policy makers at the time ARRA policies were being formulated. In a speech at the Brookings Institution in late January 2009, Alice Rivlin commented: “A long-term investment program should not be put together hastily and lumped in with the anti-recession package. The elements of the investment program must be carefully planned and will not create many jobs right away” (Suskind, 2011, p. 162). 
innovations. $^{45}$

The results in Table 6 illustrate our central conclusion: Direct transfers to households and intergovernmental transfers to states for lower-income assistance using strong matching (price) incentives are the preferred fiscal instruments for stimulating the US private economy. Direct central government purchases or unconstrained transfers to states to fund state purchases are significantly less effective as tools for macro fiscal policy. ${ }^{46}$ Had ARRA dropped federal purchases and project aid from the policy mix and reallocated those dollars to general tax relief and matching welfare aid, the efficiency performance of the stimulus package measured in GDP growth could have been significantly improved, perhaps by as much as 30 percent.

\section{Conclusions and Extensions}

The Great Recession has renewed both policy and academic interest in the ability of fiscal

\footnotetext{
${ }^{45}$ While we feel Table 6 provides a useful ranking of policies' relative effectiveness, the precise predictions should be used with caution. First, it is clear from our predicted baseline path for GDP that our estimated VAR provides a more optimistic ("V") scenario for the recovery than that ("flat U") actually observed. The likely explanation for the difference is the far-reaching crisis in the financial sector as the underlying cause of the Great Recession. Recovery from such crises is often protracted; see Reinhardt and Rogoff (2009). How might this fact bias our policy conclusions? Fiscal policies that rely upon agents' access to credit markets are likely to be those most adversely affected. This will be project aid to the SL sector as state and local governments may need to borrow funds to supplement federal aid for project spending. In contrast, direct tax relief and indirect welfare aid for SL transfers to lower income households both relax credit constraints. Thus our estimated impacts for these policies are much less likely to be affected by the current economic environment. Second, our estimated VAR does not contain any periods where monetary policy is at a "zero bound.” Thus our computed multipliers and therefore the estimated impact of ARRA policies may be understated; see, for example, Woodford (2011). For evidence there may be no significant differences in multipliers between growth and slack periods, see Owyang, Ramey, and Zubairy (2013). In any case, our relative ranking of policies' impacts is unlikely to be unaffected; see Auerbach and Gorodnichenko (2012).

${ }^{46}$ As an additional check on our SVAR results we can compare the implied cost per job of ARRA policies that we obtain from our time series, general equilibrium analysis to the direct estimates from the cross-section, partial equilibrium studies. Jobs created can be estimated applying Okun's Law relating growth in GDP to reductions in the rate of unemployment. Here we assume a 2 percent increase in GDP lowers the rate of unemployment by 1 percent; see Ball, et. al. (2013). Evaluating each policy's jobs performance by its peak impact on GDP (also within the sample periods of the cross-section studies), we estimate the fiscal cost per job created for the two classes of federal aid programs as $\$ 126,238 /$ job for ARRA innovations in welfare aid $(\triangle \mathrm{AW})$ and $\$ 312,823$ for ARRA innovations in project aid $(\triangle \mathrm{AP})$. These estimates correspond closely to those obtained by Feyrer and Sacerdote (2011) for welfare aid and Conley and Dupor (2013) for project aid, but are significantly larger than those obtained by Chodorow-Reich, et. al. (2012) for Medicaid alone. We also estimate the cost per job of ARRA innovations in direct taxation $(\Delta \mathrm{T})$ and government purchases $(\Delta \mathrm{G})$ as $\$ 39,342 /$ job for tax relief policies and $\$ 177,199 /$ job for direct federal purchases. It is reassuring perhaps that the cost per job from central government tax relief computed here is close to the estimates obtained in Carlino and Inman (2013b) of $\$ 47,000 /$ job for similar tax relief policies when all states act in unison as a "fiscal cooperative" and provide common tax relief; see Carlino and Inman (2013b), Table 4. Finally, taken as a package, the cost per job created by all original ARRA innovations together is estimated to be $\$ 84,000 / j o b$.
} 
policy to restore economies to full employment. In the US, the response was ARRA, which provided \$381 billion in federal tax cuts, \$98 billion in federal government purchases, and \$318 billion in transfers to state and local governments to fund their own tax relief and spending strategies. As a federal union, the US public economy relies to a significant degree upon its state and local governments to provide nondefense government services, to administer poverty relief, and to share in the financing of such services and transfers. If the central government wishes to expand state and local spending or tax relief in times of an economic downturn, it will need to motivate lower-tier governments to do so. Other than by fiat, which is both constitutionally prohibited or politically infeasible in most economic unions, centrally funded intergovernmental transfers are the required fiscal policy. This paper has sought to understand the likely impact of such assistance on US economy’s macroeconomic performance. Our analysis offers three conclusions.

First, the impact on the aggregate economy of federal transfers to state and local governments is not equivalent to that of federal tax cuts and transfers paid directly to individuals or firms. For the US economy, the average dollar given to the private sector is significantly more stimulative - i.e., it has a larger multiplier - than the average dollar given to lower-tier governments. Transfers to governments must be evaluated as a separate fiscal policy distinct in its macroeconomic impacts from those of taxes and transfers to the private sector.

Second, in economic unions, lower-tier governments are independently elected. As independent agents, they have their own agendas. Accordingly, care must be taken to understand how, and for what purpose, intergovernmental transfers are given to state and local governments. The structure of incentives matters. From our analysis of state government fiscal choices, we find price (i.e., matching grants) incentives are more effective than are income (i.e., unconstrained) incentives in stimulating tax and spending behaviors. Unconstrained intergovernmental transfers, or fungible program aid, provide general support for state and local governments' budgets. In the case of US states, we find $\$ .50$ of each dollar increase in such assistance is saved and only slowly spent in future years. In contrast, matching aid targeted for welfare services is fully spent on tax relief or low-income assistance and is paid only when such services or transfers are provided. The purpose of intergovernmental aid matters too. From our analysis of the macroeconomic impact of fiscal policies, assistance for tax relief or income transfers is more stimulative than assistance for government purchases. Together, these two facts help us understand why, at least for the US public 
economy, welfare aid (AW) is significantly more stimulative to the aggregate economy than is project aid (AP).

Third, recognizing such differences in how, and for what purpose, intergovernmental aid is given is important for the efficient design of macro-stabilization fiscal policies. In the case of ARRA, reallocating all federal government direct purchases to federal tax relief and all intergovernmental project aid to welfare assistance would have improved estimated income growth from ARRA funding by about 30 percent.

Though based on US data and US political institutions, we feel our central lessons have applications for other current, or would-be, federal economies. For example, the current economic crisis within the European Monetary Union has again raised calls for a stronger fiscal union, and therefore union-wide fiscal policies, to complement the European Central Bank and monetary policy in combating economic recessions. Given the Union's strong commitment to the principle of subsidiarity, it seems inevitable that if such a fiscal union were to emerge, intergovernmental transfers would be a central fiscal tool for achieving Union-wide objectives. At the moment, EU intergovernmental transfers are a small share of any member country's budget and paid only as fungible project aid. How to best design new transfers to help stabilize the Union's macroeconomy, recognizing that member countries will be independent economic agents, will be an important extension of our work here.

Also valuable would be an analysis of how intergovernmental transfer policies are chosen within fiscal unions, recognizing the role of states, now not as agents but as principals, in congressional politics setting fiscal policies. From this perspective, perhaps it is no surprise that ARRA required a significant component of fungible project aid to states for its passage, even though such aid appears much less efficient than targeted welfare aid for achieving ARRA's stated objective of quickly restoring the economy to a path of positive growth. Exactly which political institutions provide the best opportunity to choose efficient fiscal policies is a wider question, but one clearly relevant to the design of macro fiscal policies in economic unions. 


\section{REFERENCES}

Auerbach, A. (2003), “Fiscal Policy, Past and Present,” Brookings Papers on Economic Activity, No. $1,75-122$.

Auerbach, A. and Y. Gorodnichenko (2012), "Measuring Output Responses to Fiscal Policy," American Economic Journal: Economic Policy, Vol. 4 (May), 1-27.

Auerbach, A. and Y. Gorodnichenko (2013), “Output Spillovers from Fiscal Policy,” American Economic Review, Vol. 103 (May), 141-146.

Ball, L., D. Leigh, and P. Loungani (2013), “Okun’s Law: Fit at Fifty?” NBER Working Papers, WP 18668.

Barro, R. and C. Redlick (2011), "Macroeconomic Effects of Government Purchases and Taxes,” Quarterly Journal of Economics, Vol. 126 (February), 51-102.

Beetsma, R. and M. Giuliodori (2011), “The Effects of Government Purchase Shocks: Review and Estimates for the EU,” Economic Journal, Vol. 121 (February), F4-F32.

Berry, W., R. Fording, E. Ringquist, R. Hanson, and C. Klarner (2010), “Measuring Citizen and Government Ideology in the US States: A Re-appraisal,” State Politics and Policy Quarterly, Vol. 10 (Summer), 117-135.

Blanchard, O. and R. Perotti (2002), “An Empirical Characterization of the Dynamic Effects of Changes in Government Spending and Taxes on Output,” Quarterly Journal of Economics, Vol. 117 (November), 1329-1368.

Bohn, H. and R. P. Inman (1996), "Balanced Budget Rules and Public Deficits: Evidence from US States,” Carnegie-Rochester Conference on Public Policy, Vol. 45 (December), 13-76.

Bound, J., D. Jaeger, and R. Baker (1995), “Problems with Instrumental Variables Estimation When Correlation Between the Instruments and Endogenous Explanatory Variables Is Weak,” Journal of the American Statistical Association, Vol. 90 (430), 443-450.

Carlino, G. and R. P. Inman (2013a), “A Narrative Analysis of Post World War II Changes in Federal Aid,” Federal Reserve Bank of Philadelphia, Research Paper No. 12-23/R.

Carlino, G. and R. P. Inman (2013b), “Local Deficits and Local Jobs: Can US States Stabilize Their Own Economies?” Journal of Monetary Economics, Vol. 60 (July), 517-530.

Chernick, H. (1998), "Fiscal Effects of Block Grants for the Needy: An Interpretation of the Evidence,” International Tax and Public Finance, Vol. 5 (May), 205-233. 
Chodorow-Reich, G., L. Feiveson, A. Liscow, and W. Woolston (2012), “Does State Fiscal Relief During Recessions Increase Employment? Evidence from the American Recovery and Reinvestment Act,” American Economic Journal: Economic Policy, Vol. 4 (August), 118-145.

Cohen, L., J. Coval, and C. Mallory (2011), "Do Powerful Politicians Cause Corporate Downsizing?” Journal of Political Economy, Vol. 119 (December), 1015-1060.

Conley, T. and B. Dupor (2013), "The American Recovery and Reinvestment Act: Solely a Government Jobs Program? Journal of Monetary Economics, Vol. 60 (July), 535-549.

Craig, S. and R. P. Inman (1982). "Federal Aid and Public Education: An Empirical Look and the New Fiscal Federalism," Review of Economics and Statistics, Vol. 64 (November), 541-552.

Engemann, K., M. Owyang, and S. Zubairy (2008), "A Primer on the Empirical Identification of Government Spending Shocks,” Federal Reserve Bank ofSt. Louis Review (March/April), 117-132.

Favero, C. and F. Giavazzi (2012), "Measuring Tax Multipliers: The Narrative Method in Fiscal VARs,” American Economic Journal: Economic Policy, Vol. 4 (May), 69-94.

Feyrer, J. and B. Sacerdote (2011), "Did the Stimulus Stimulate? Real Time Estimates of the Effects of the American Recovery and Reinvestment Act,” NBER Working Paper No. 16759.

Finkelstein, Amy, et al. (2012), "The Oregon Health Insurance Experiment: Evidence from the First Year,” Quarterly Journal of Economics, Vol. 127 (August), 1057-1106.

Fishback, P. and V. Kachanovskaya (2010), "In Search of the Multiplier for Federal Spending in the States During the New Deal,” NBER Working Papers, WP 16561.

Follette, G. and B. Lutz (2010), "Fiscal Policy in the United States: Automatic Stabilizers, Discretionary Fiscal Policy Actions, and the Economy," Finance and Economics Discussion Series, Federal Reserve Board, 2010-43.

Gramlich, E. (1978), "State and Local Budgets the Day After It Rained: Why Is the Surplus So High?” Brookings Papers on Economic Activity, No. 1., 191-216.

Gramlich, E. (1979), "Stimulating the Macro Economy Through State and Local Governments," American Economic Review, Vol. 69 (May), 180-185.

Hebous, S. and T. Zimmermann (2013), "Estimating the Effects of Coordinated Fiscal Actions in Euro Zone,” European Economic Review, Vol. 58 (February), 110-121.

Holtz-Eakin, D., H. Rosen, and S. Tilly (1994), "Intertemporal Analysis of State and Local Government Spending: Theory and Tests,” Journal of Urban Economics, Vol. 35 (March), 139-174. 
Inman, R. P. (2007), “Federalism's Values and the Value of Federalism,” CESifo Economic Studies, Vol. 53 (December), 522-560.

Johnson, D., J. Parker, and N. Souleles (2006), "Household Expenditure and the Income Tax Rebates of 2001,” American Economic Review, Vol. 96 (December), 1589-1610.

Keith, R. and A. Schick (2004), "Introduction to the Federal Budget Process," Congressional Research Service, 98-721 GOV (updated, December 28, 2004).

Knight, B. (2002), "Endogenous Federal Grants and Crowd-Out of State Government Spending: Theory and Evidence from the Federal Highway Aid Program,” American Economic Review, Vol. 92 (March), 71-92.

Ladd, H. (1993), "State Responses to the TRA86 Revenue Windfalls: A New Test of the Flypaper Effect,” Journal of Policy Analysis and Management, Vol. 12 (Winter), 82-103.

Leduc, S. and D. Wilson (2013), “Are State Governments Roadblocks to Federal Stimulus? Evidence from Highway Grants in the 2009 Recovery Act," Federal Reserve Bank of San Francisco, WP 2013-16.

Leeper, E., T. Walker, and S-CS. Yang (2010), “Government Investment and Fiscal Stimulus in the Short and Long Run,” Journal of Monetary Economics, Vol. 57 (November), 1000-1012.

Melitz, J. and F. Zumer (2002), "Regional Redistribution and Stabilization by the Center in Canada, France, the UK, and the US: A Reassessment and New Tests,” Journal of Public Economics, Vol. 86 (November), 263-286.

Mertens, K. and M. O. Ravn (2012), "Empirical Evidence on the Aggregate Effects of Anticipated and Unanticipated US Tax Policy Shocks,” American Economic Journal: Economic Policy, Vol. 4 (May), 145-181.

Mertens, K. and M. O. Ravn (2013),”A Reconciliation of SVAR and Narrative Estimates of Tax Multipliers," Journal of Monetary Economics, forthcoming.

Mountford, A. and H. Uhlig (2009), “What Are the Effects of Fiscal Policy Shocks?” Journal of Applied Econometrics, Vol. 24 (September-October), 960-992.

Nakamura, E. and J. Steinsson (2011), "Fiscal Stimulus in a Monetary Union: Evidence from U.S. Regions,” NBER Working Papers, WP 17391.

Owyang, M., V. Ramey, and S. Zubairy (2013), “Are Government Spending Multipliers Greater during Periods of Slack? Evidence from the $20^{\text {th }}$ Century Historical Data," American Economic Review, Vol. 103 (May), 129-134. 
Ramey, V. (2011a), “Identifying Government Spending Shocks: It’s All in the Timing,” Quarterly Journal of Economics, Vol. 126 (February), 1-50

Ramey, V. (2011b), “Can Government Purchases Stimulate the Economy?” Journal of Economic Literature, Vol. 49 (September), 673-685.

Ramey, V. and M. Shapiro (1998), "Costly Capital Reallocation and the Effects of Government Spending,” Carnegie-Rochester Conference on Public Policy, Vol. 48 (June), 145-194.

Reinhardt, C. and K. Rogoff (2009), “The Aftermath of Financial Crises,” NBER Working Papers, WP 14656.

Reischauer, R. (1975), “General Revenue Sharing: The Program’s Incentives,” in W. Oates (ed.), Financing the New Federalism: Revenue Sharing, Conditional Grants, and Taxation, Baltimore: Johns Hopkins University Press.

Romer, C. and D. Romer (2010), "The Macroeconomic Effects of Tax Changes: Estimates Based on a New Measure of Fiscal Shocks,” American Economic Review, Vol. 100 (June), 763-801.

Rossi, B. and S. Zubairy (2011), "What Is the Importance of Monetary and Fiscal Shocks in Explaining US Macroeconomic Fluctuations?” Duke University, Department of Economics.

Sims, C. (1998), “Comment on Glenn Rudebusch’s ‘Do Measures of Monetary Policy in a VAR Make Sense?’ International Economic Review, Vol. 39 (November), 933-941.

Singhal, M. (2008), "Special Interest Groups and the Allocation of Public Funds," Journal of Public Economics, Vol. 92 (April), 548-564.

Suarez-Serrato, J. C. and P. Wingender (2011), “Estimating Local Fiscal Multipliers,” University of California, Berkeley, Economics Department.

Suskind, R. (2011), Confidence Men: Wall Street, Washington, and the Education of a President, New York: HarperCollins.

Taylor, J. (2011), “An Empirical Analysis of the Revival of Fiscal Activism in the 2000s,” Journal of Economic Literature, Vol. 49 (September), 686-702.

United States Department of Transportation (2007), Financing Federal-Aid Highways, Publication No. FHWA-PL-07-017, March.

Wilson, D. (2012), "Fiscal Spending Jobs Multipliers: Evidence from the 2009 American Recovery and Reinvestment Act,” American Economic Journal: Economic Policy, Vol. 4 (August), 251-282. 
Woodford, M. (2011), “The Simple Analytics of the Government Expenditure Multiplier,” American Economic Journal: Macroeconomics, Vol. 3 (January), 1-35. 
TABLE 1: Narrative Federal Aid Dates and Funding

\begin{tabular}{|c|c|c|}
\hline PROGRAM & TIMING & LEVEL OF AID* \\
\hline Federal Highway Act of 1956 & $1957: 3$ to $1958: 2$ & \$1.518 Billion \\
\hline Housing Act of 1954 & $1958: 3$ to $1959: 2$ & \$.041 Billion \\
\hline Elementary and Secondary Education Act of 1965 & $1965: 3$ to $1966: 2$ & \$1.4 Billion \\
\hline Medicaid & $1967: 3$ to $1968: 2$ & \$1.805 Billion \\
\hline Housing and Urban Development Act of 1968 & $1969: 3$ to $1970: 2$ & \$.579 Billion \\
\hline Model Cities & $1970: 3$ to $1971: 2$ & \$1.5 Billion \\
\hline General Revenue Sharing (GRS) & $1972: 4$ to $1974: 2$ & $\$ 6.636$ Billion \\
\hline Public Works Employment Act of 1976 & $1976: 3$ to $1977: 2$ & \$3.25 Billion \\
\hline Economic Stimulus Appropriations Act of 1977 & $1977: 2$ to $1978: 2$ & $\$ 4.0$ Billion \\
\hline Intergovernmental Anti-Recession Act of 1977 & $1977: 2$ to $1978: 2$ & \$2.25 Billion \\
\hline Reauthorization of CETA & $1977: 2$ to $1978: 2$ & \$6.6 Billion \\
\hline Discontinuation of GRS (State Portion) & $1981: 4$ to $1983: 2$ & $-\$ 2.283$ Billion \\
\hline Discontinuation of GRS (Local Portion) & $1983: 4$ to $1984: 2$ & -\$3.481 Billion \\
\hline Emergency Job Act of 1983 (Part I) & $1983: 3$ to $1984: 2$ & $\$ 4.381$ Billion \\
\hline Emergency Job Act of 1983 (Part II) & $1984: 3$ to $1985: 2$ & \$4.487 Billion \\
\hline Welfare Reform of 1996 (PRWORA) & $1997: 3$ to $1998: 2$ & -\$1.710 Billion \\
\hline Tobacco Settlement Agreement & $1998: 4$ to $2000: 2$ & \$118.28 Billion \\
\hline No Child Left Behind Act of 2001 & $2002: 3$ to $2003: 2$ & \$1.993 Billion \\
\hline Job and Growth Tax Reconciliation Act of 2003 & $2003: 2$ to $2004: 2$ & \$10.0 Billion \\
\hline $\begin{array}{l}\text { American Recovery and Reinvestment Act of } 2009 \\
\text { (Medicaid Relief and “Stability” Aid) }\end{array}$ & 2009:2 to $2010: 2$ & $\$ 37.03$ Billion \\
\hline $\begin{array}{l}\text { American Recovery and Reinvestment Act of } 2009 \\
\text { (Project Aid for Transportation and Housing) }\end{array}$ & 2010:3 to 2011:2 & \$18.753 Billion \\
\hline
\end{tabular}

* All levels of aid are in nominal dollars. While listed as separate narrative episodes above, the three events occurring during the common period 1977:2 to 1978:2 and the overlapping episodes for the period 1983:3 to 1984:2 are combined into single narrative events for purposes of estimation. The Emergency Job Act of 1983, the Job and Growth Tax Reconciliation Act of 2003, and the American Recovery and Reinvestment Act of 2009 each provided assistance in response to a recession. We specify the narrative aid variable as "unanticipated aid" equal to the difference between aid budgeted by the act and the aggregate level of state deficits accumulated during the recession period. Aid paid under the Public Works Employment Act of 1976, the Economic Stimulus Appropriations Act of 1977, the Intergovernmental Anti-Recession Act of 1977, and the reauthorization of CETA is treated as new aid. The 1973-75 recession was the first recession after which the federal government offered post-recession fiscal assistance. Consistent with this specification of unanticipated aid, we also allow for one "non-event" in the narrative record: the failure of Congress to provide state deficit relief following the 1991 recession. See Carlino and Inman (2013a) for details. 


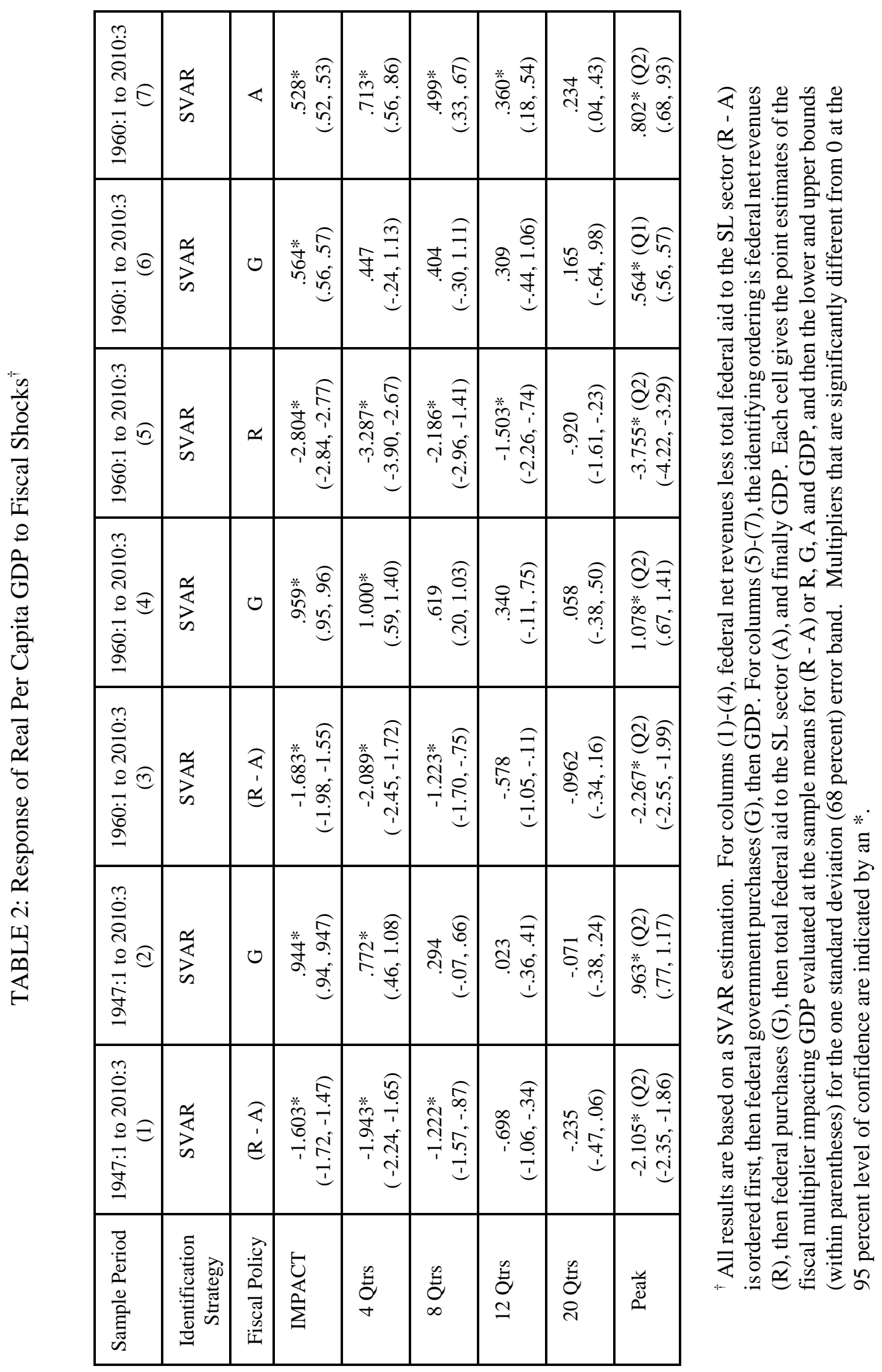




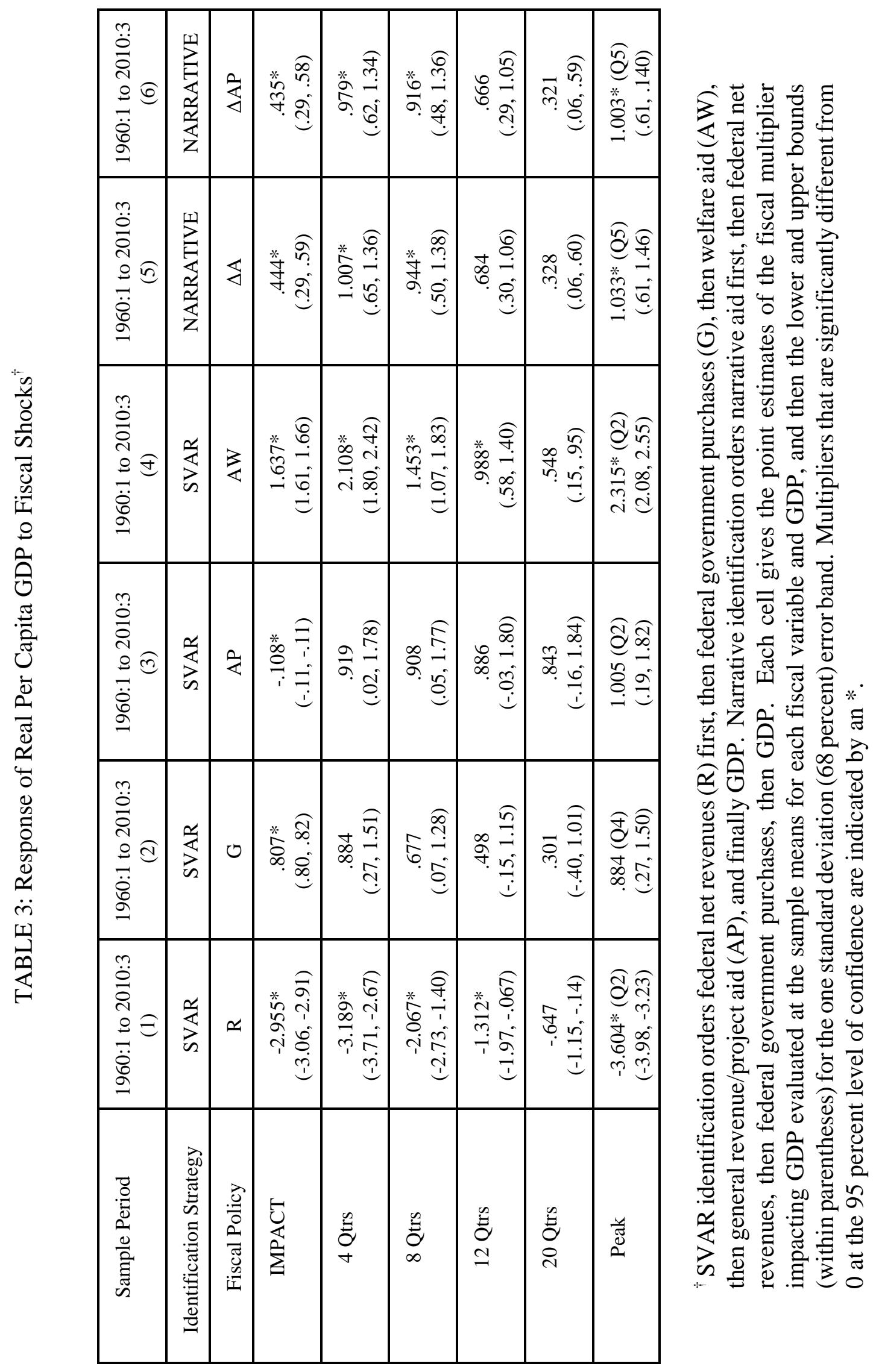




\begin{tabular}{|c|c|c|c|c|c|c|c|c|}
\hline 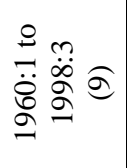 & 蛋 & $\frac{3}{4}$ & 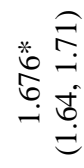 & 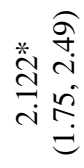 & 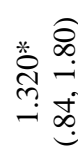 & 壳 & 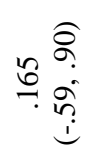 & 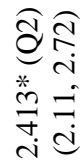 \\
\hline 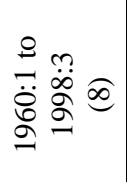 & 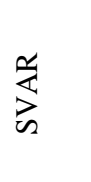 & $\stackrel{2}{\alpha}$ & 孚 & 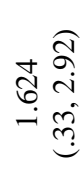 & 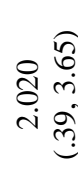 & 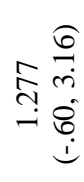 & 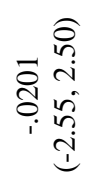 & 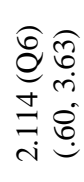 \\
\hline $\begin{array}{l}\frac{x}{\sqrt[y]{1}} \\
\frac{2}{0}\end{array}$ & 恋 & $\frac{3}{4}$ & 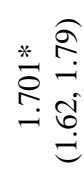 & 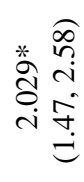 & 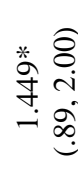 & 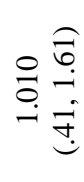 & 突 & 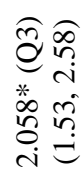 \\
\hline 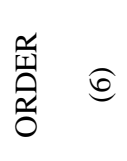 & 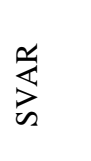 & \& & 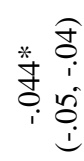 & 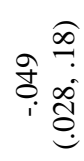 & 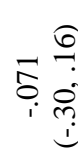 & 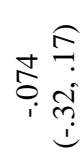 & 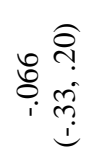 & 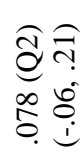 \\
\hline 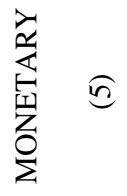 & 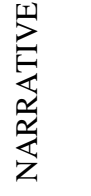 & 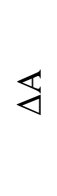 & 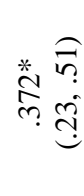 & 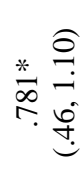 & 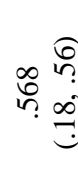 & 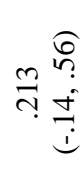 & 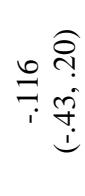 & 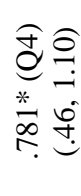 \\
\hline 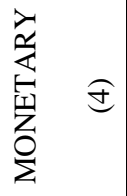 & 蛋 & $\frac{3}{4}$ & 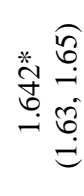 & 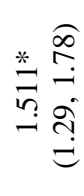 & 今ึ & 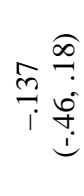 & 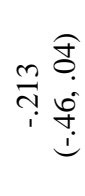 & 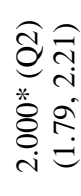 \\
\hline 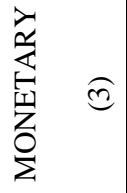 & 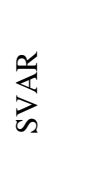 & \& & 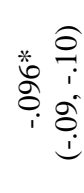 & 导 & 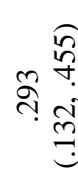 & 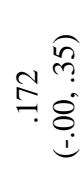 & 总 & 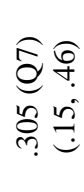 \\
\hline$\underset{\substack{\| \\
0_{0}^{\infty}}}{0} \widehat{a}$ & 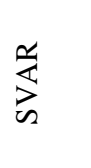 & $\frac{3}{4}$ & 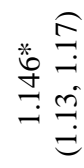 & 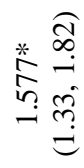 & 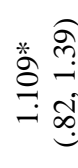 & 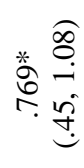 & 守. & 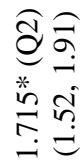 \\
\hline 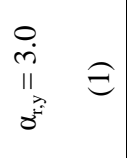 & 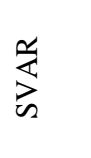 & $\stackrel{2}{\&}$ & 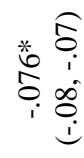 & 䒘 & م. & 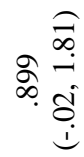 & 点 & 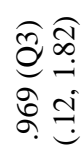 \\
\hline 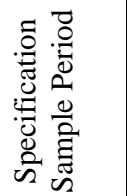 & 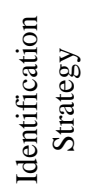 & 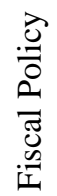 & 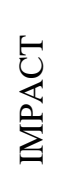 & $\begin{array}{l}\mathscr{a} \\
\vdots \\
\forall\end{array}$ & $\begin{array}{l}\infty \\
0 \\
\infty\end{array}$ & 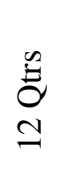 & $\begin{array}{l}\stackrel{0}{0} \\
\text { Oे } \\
\text { থ }\end{array}$ & 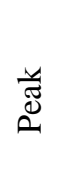 \\
\hline
\end{tabular}

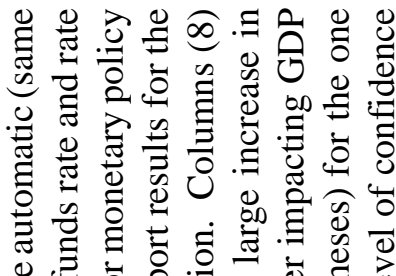

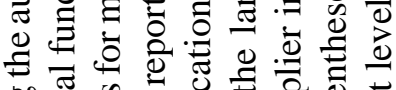

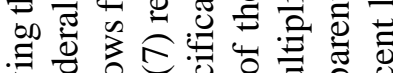

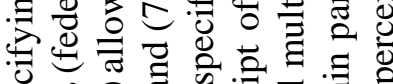

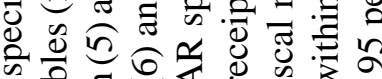
की

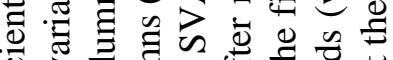

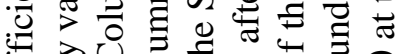
矛记

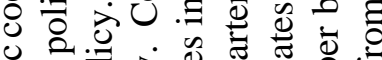

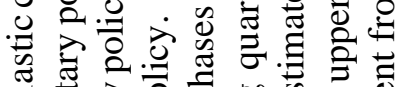

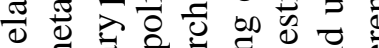

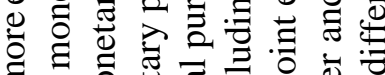

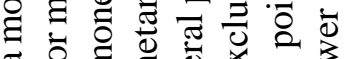
훈 $\cong$ 3े สิ

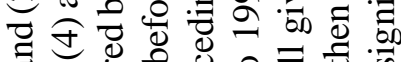
ฮั Эี

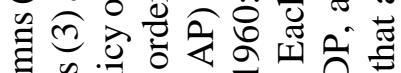

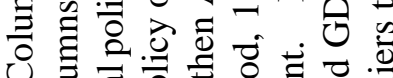

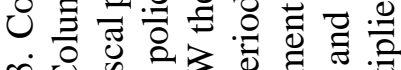

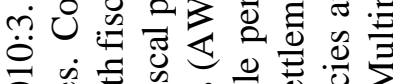

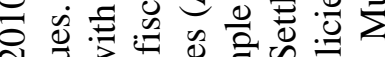
ํ.

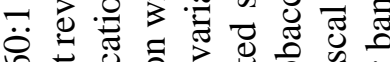
ठे

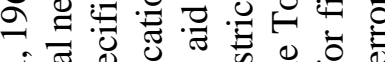
वें

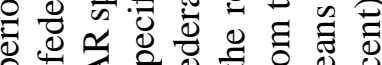

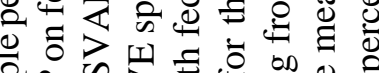

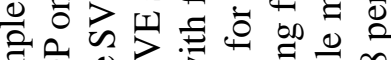

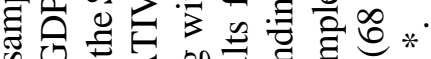

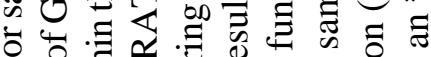

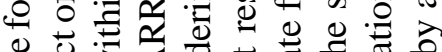

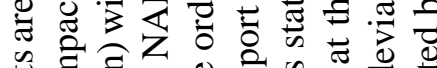

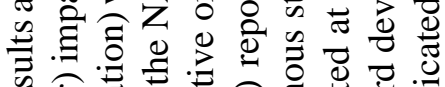

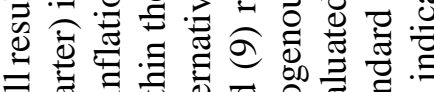

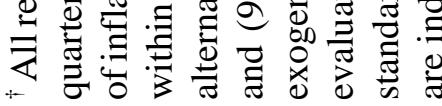




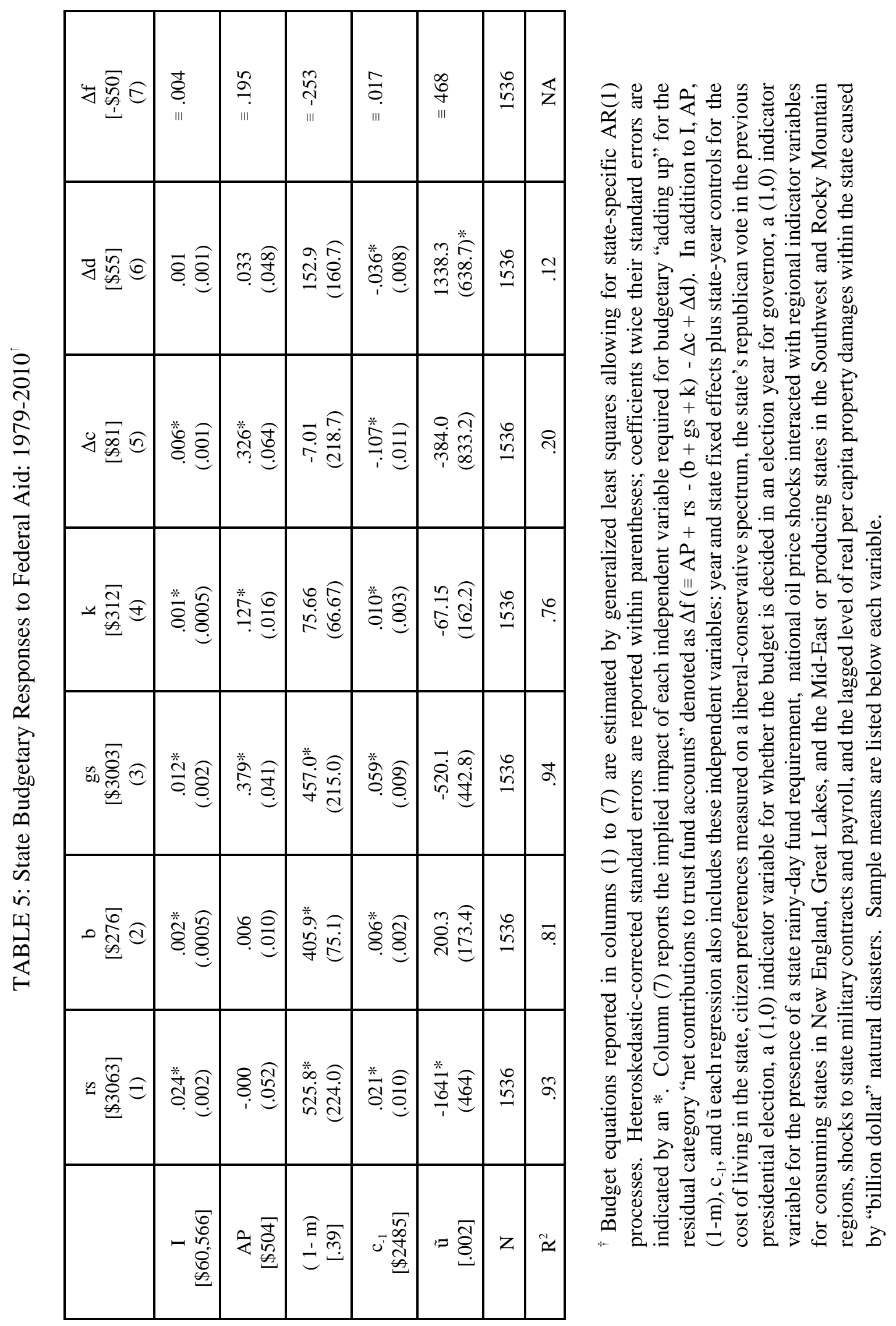




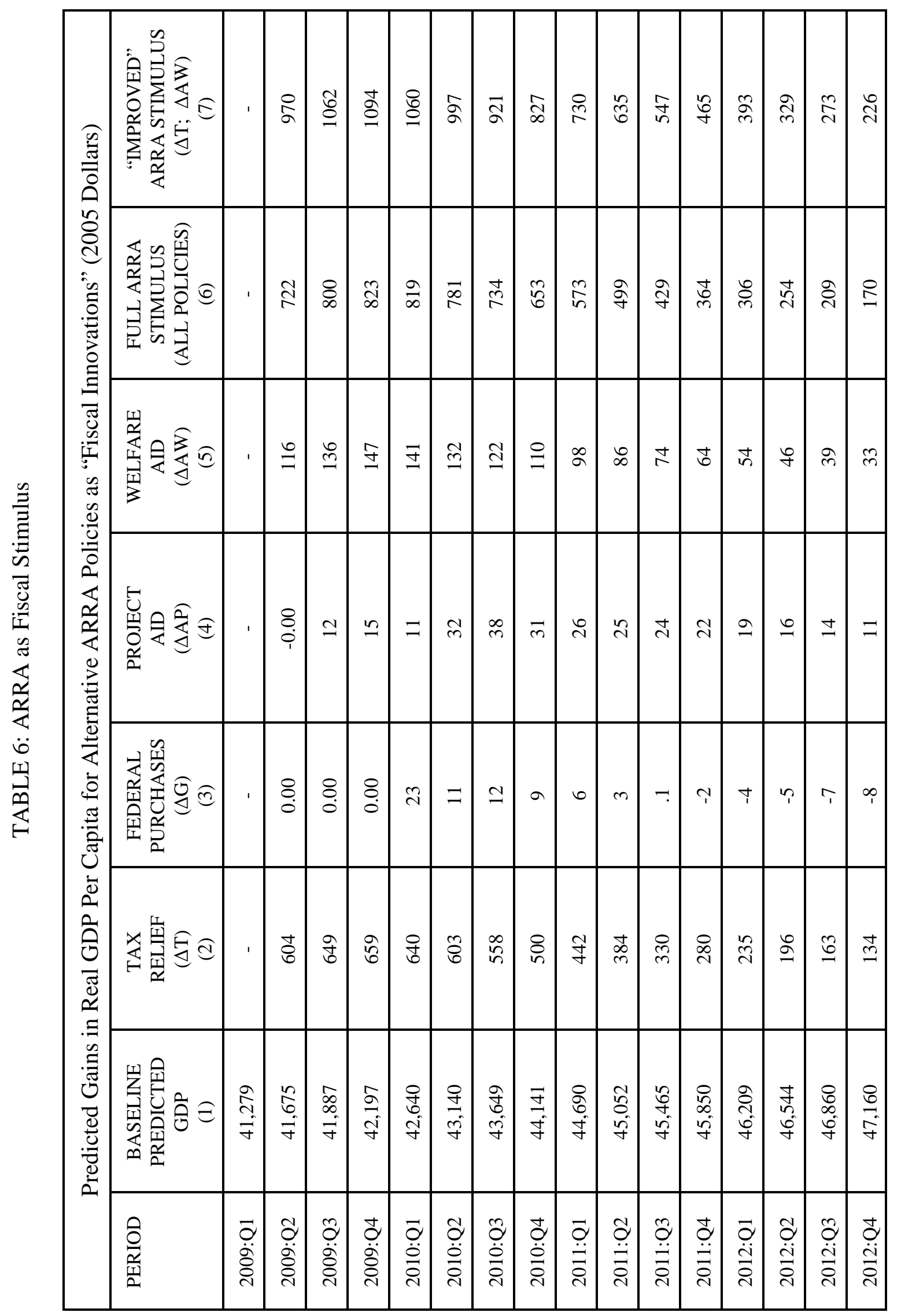


Federal Aid, Federal Purchases, and Federal Net Revenue: 1947 - 2010* (Per Capita, 2005 Dollars)

Figure 1

Total Aid, Welfare Aid, and Project Aid

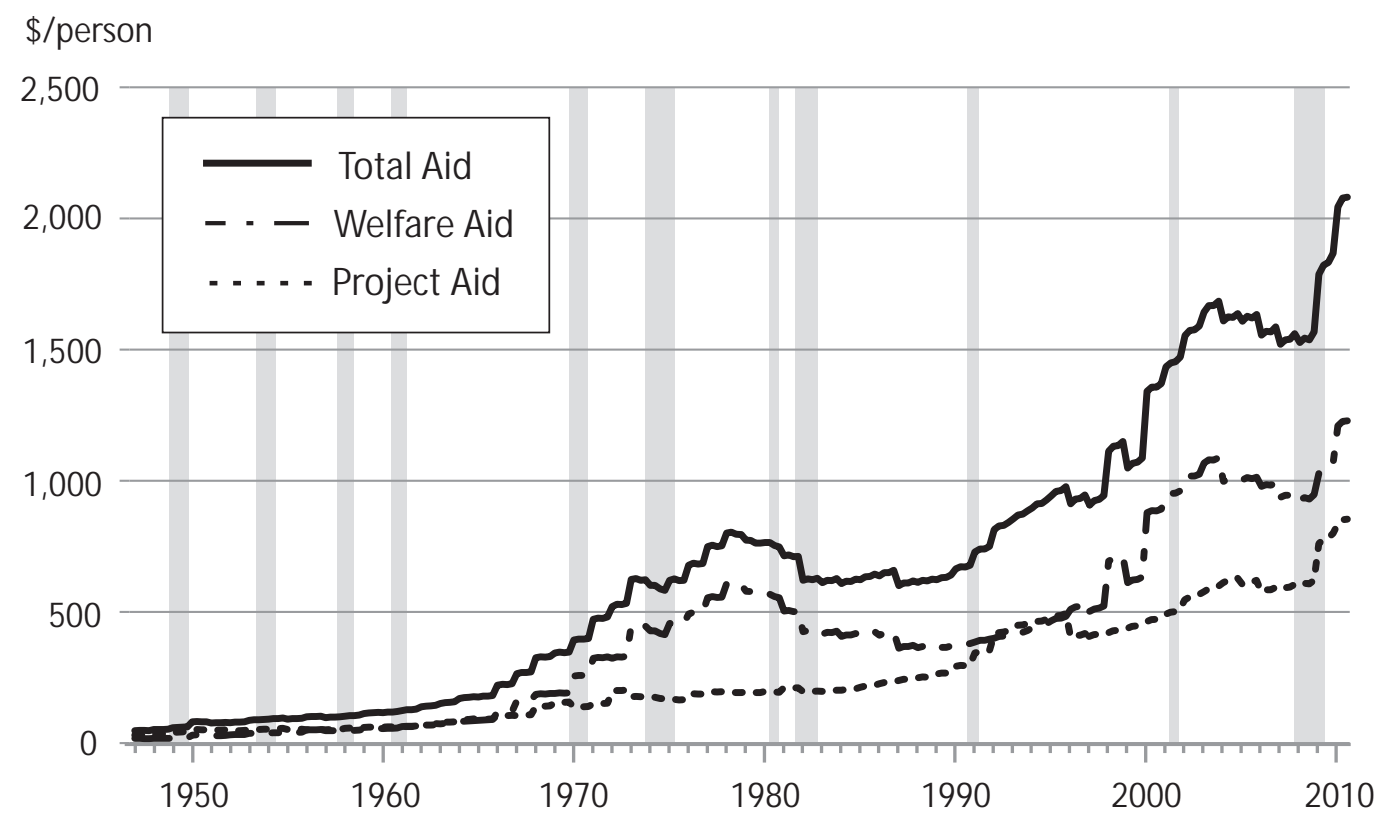

Figure 2

Federal Purchases and Federal Net Revenue

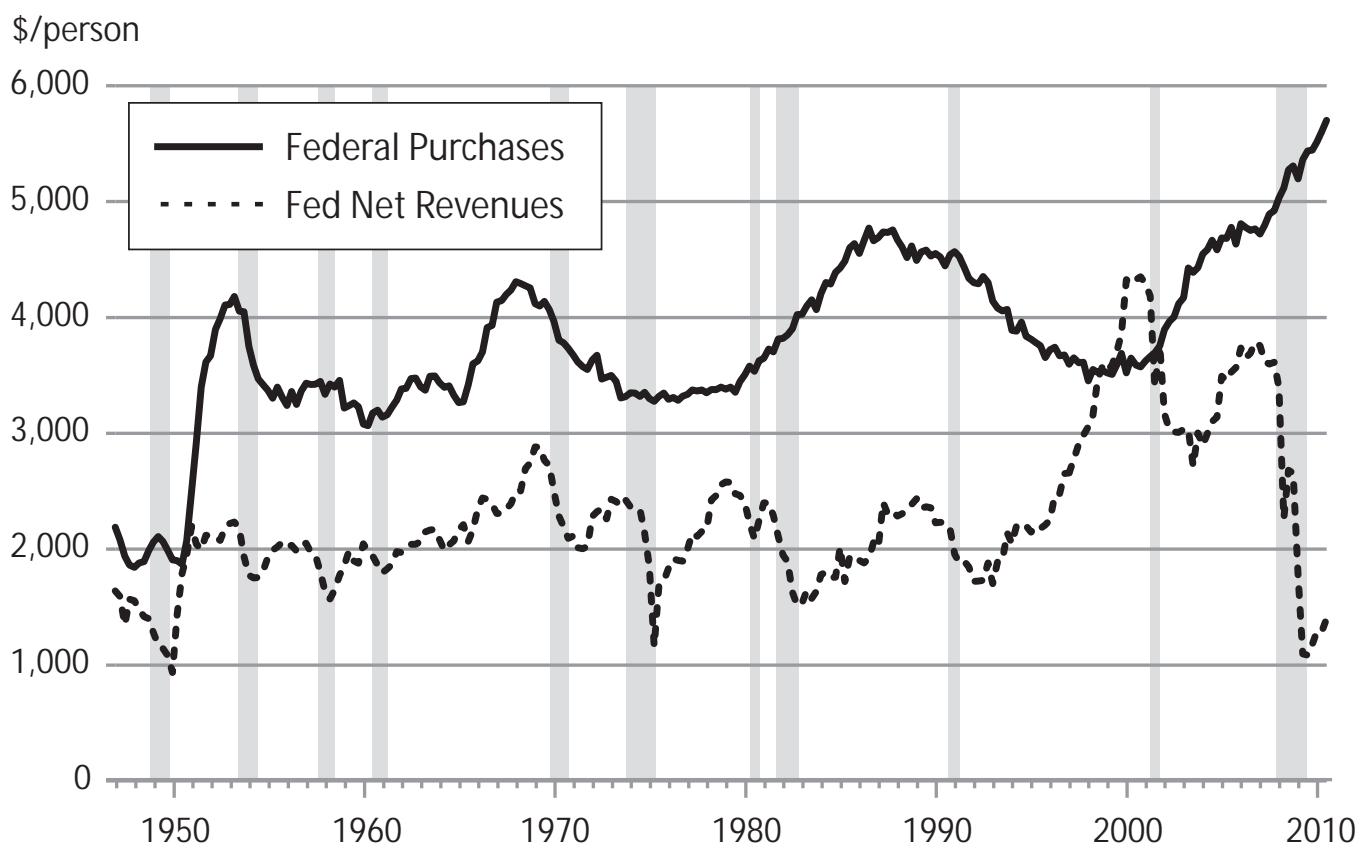

* Recession years shown as shaded bands 


\section{Figure 3: Comparison of Structural and Narrative Aid Innovations (Dollars per Person)}

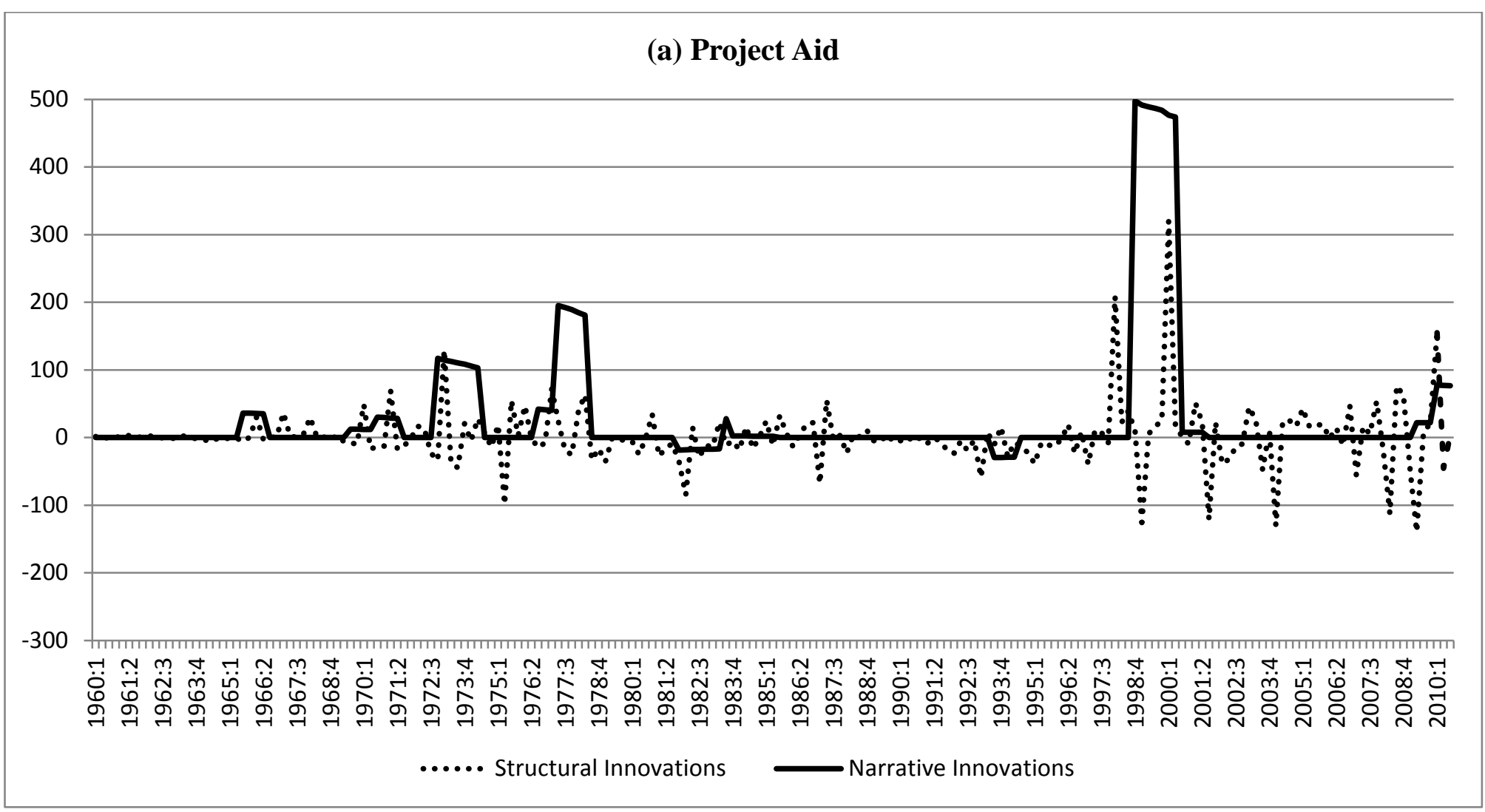

\section{(b) Welfare Aid}

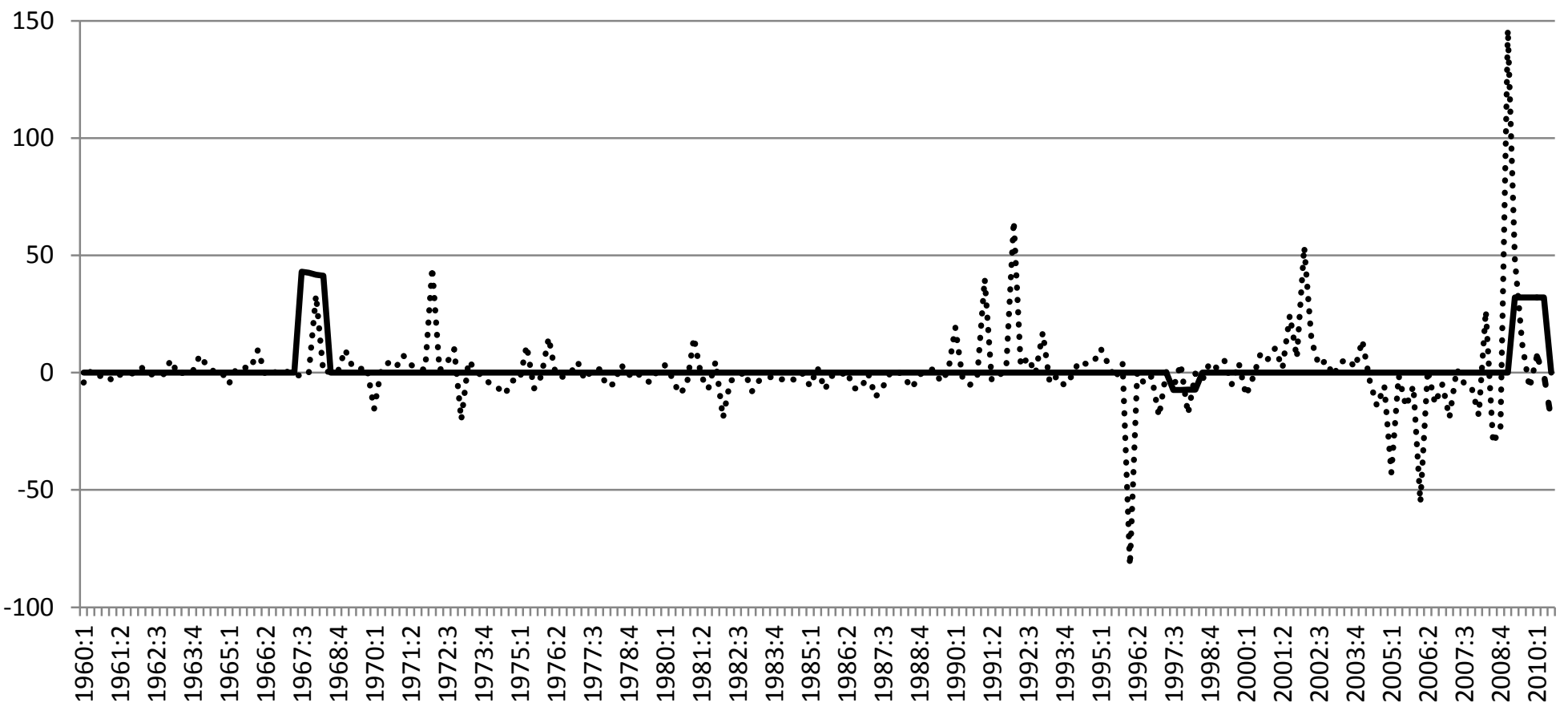

